\title{
Ecology, evolution and spillover of coronaviruses from bats
}

Manuel Ruiz-Aravena (1) ${ }^{1,12}$, Clifton McKee ${ }^{2,12}$, Amandine Gamble ${ }^{3}$, Tamika Lunn ${ }^{4}$, Aaron Morris, Celine E. Snedden', Claude Kwe Yinda ${ }^{6}$, Julia R. Port ${ }^{6}$, David W. Buchholz', Yao Yu Yeo $\mathbb{1}^{7}$, Christina Faust ${ }^{8}$, Elinor Jax ${ }^{5}$, Lauren Dee ${ }^{5}$, Devin N. Jones ${ }^{1}$, Maureen K. Kessler (1) ${ }^{1,11}$, Caylee Falvo', Daniel Crowley', Nita Bharti ${ }^{8}{ }^{3}$, Cara E. Brook ${ }^{9}$,

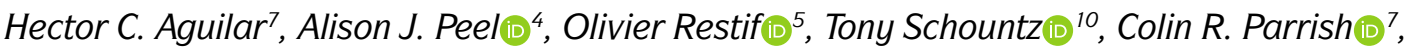
Emily S. Gurley², James O. Lloyd-Smith $\mathbb{1}^{3}{ }^{3}$, Peter J. Hudson ${ }^{8}$, Vincent J. Munster $\mathbb{D}^{6}$ and Raina K. Plowright $\mathbb{D}^{1 凶}$

Abstract | In the past two decades, three coronaviruses with ancestral origins in bats have emerged and caused widespread outbreaks in humans, including severe acute respiratory syndrome coronavirus 2 (SARS-CoV-2). Since the first SARS epidemic in 2002-2003, the appreciation of bats as key hosts of zoonotic coronaviruses has advanced rapidly. More than 4,000 coronavirus sequences from 14 bat families have been identified, yet the true diversity of bat coronaviruses is probably much greater. Given that bats are the likely evolutionary source for several human coronaviruses, including strains that cause mild upper respiratory tract disease, their role in historic and future pandemics requires ongoing investigation. We review and integrate information on bat-coronavirus interactions at the molecular, tissue, host and population levels. We identify critical gaps in knowledge of bat coronaviruses, which relate to spillover and pandemic risk, including the pathways to zoonotic spillover, the infection dynamics within bat reservoir hosts, the role of prior adaptation in intermediate hosts for zoonotic transmission and the viral genotypes or traits that predict zoonotic capacity and pandemic potential. Filling these knowledge gaps may help prevent the next pandemic.

\section{Planetary health} approaches Ecological approaches to understanding the impact of anthropogenic disruption of natural systems on human health.

\footnotetext{
凶e-mail: raina.plowright@ montana.edu

Bats are the reservoir hosts of three of the ten virus groups of pandemic concern, as designated by the World Health Organization: henipaviruses (Nipah virus and Hendra virus), filoviruses (Ebola virus and Marburg virus) and coronaviruses ${ }^{1}$. Common features among these emerging viruses include the ability to cause severe disease in humans but not in the reservoir hosts, rare spillovers despite a wide geographical distribution and the potential role of bridging hosts that increase opportunities for human infections. The recent spillovers of bat coronaviruses to humans are consistent with an increasing number of emergent zoonoses from wildlife ${ }^{2,3}$. Wildlife farming and trade facilitate cross-species transmission of viruses by mixing species in stressful and crowded conditions ${ }^{4-6}$, while other behaviours, including hunting and guano mining, facilitate contact with bat-borne pathogens. Those are part of larger patterns of encroachment into wildlife habitats and increasing pressure from human population expansion and intensifying natural resource use. The COVID-19 pandemic has highlighted the need for integrated planetary health approaches to understanding spillover as a multilayered process. Here, we focus on bat coronaviruses and the ecological, evolutionary and epidemiological features that influence the risk of spillover into humans and subsequent epidemic emergence.

Bats are the second most diverse order of mammals, with more than 1,400 species, and they host an exceptional diversity of coronaviruses with ancient viral lineages that are spread across all six continents that bats inhabit. More than 4,800 coronavirus sequences have been detected in bats, accounting for more than $30 \%$ of all bat viruses sequenced ${ }^{7}$. Given that 543 bat species - from a global diversity of 1,435 - have been sampled for coronaviruses (Supplementary Table 1), the true diversity of bat coronaviruses is likely much greater. Bats are hosts of ancestral lineages of betacoronaviruses from which viruses of public health concern evolved, including severe acute respiratory syndrome coronavirus (SARS-CoV), Middle East respiratory syndrome coronavirus (MERS-CoV) and SARS-CoV-2. These recent cases may just be the latest in a longer history 
of spillover and emergence of bat coronaviruses into humans. For example, of the four endemic human coronaviruses that cause $30 \%$ of mild upper respiratory tract infections (common cold), two may have originated in bats (alphacoronaviruses human coronavirus 229E (HCoV-229E) and HCoV-NL63) ${ }^{8}$. Thus, the ancestry of at least five of the seven coronaviruses capable of human-to-human transmission can be traced back to bat coronaviruses ${ }^{9,10}$. The other two human coronaviruses (HCoV-OC43 and $\mathrm{HCoV}-\mathrm{HKU} 1$ ) also may have spilled over from animals to humans, with pathways that may involve rodents and cattle ${ }^{11}$. Additionally, animal coronaviruses might have evolutionary origins in lineages from bats, such as the recently emerged coronavirus causing severe acute diarrhoea syndrome in pigs ${ }^{12}$. Serological evidence of exposure of humans to bat coronaviruses in rural China suggest that spillovers from bats might occur relatively frequently but are not detected ${ }^{13,14}$.

Here, we review the ecology, evolution and spillover of bat coronaviruses and assess the current knowledge of the determinants of coronavirus spillover and transmission among recipient hosts - from the ecology of hosts and viruses to single virus-cell interactions. We further highlight the knowledge gaps that prevent us from preparing for and mitigating coronavirus emergence risk and suggest a research agenda for developing the science of preventing coronavirus spillover.

\section{Distribution of bat coronaviruses}

Coronaviruses (order Nidovirales, family Coronaviridae) include four genera: Alphacoronavirus and Betacoronavirus, which infect a broad range of mammals, and Gammacoronavirus and Deltacoronavirus, which primarily infect birds ${ }^{15}$. Since the emergence of SARS-CoV in 2002 , and the evidence that it originated from a bat reservoir, coronaviruses have been detected in $16 \%$ of bat species (238) (Supplementary Table 1). Alphacoronaviruses and betacoronaviruses have been detected in bats from 14 of the 21 bat families, in at least 69 countries across six continents (FICS 1,2; TABLE 1; Supplementary Table 1). The diversity of coronaviruses found in bats is high, with more than 60 coronavirus species (more than 4,000 individual sequences) detected from 13 of the 19 known mammalian

\footnotetext{
Author addresses

${ }^{1}$ Department of Microbiology and Cell Biology, Montana State University, Bozeman, MT, USA.

${ }^{2}$ Department of Epidemiology, Johns Hopkins Bloomberg School of Public Health, Baltimore, MD, USA.

${ }^{3}$ Department of Ecology and Evolutionary Biology, University of California, Los Angeles, Los Angeles, CA, USA.

${ }^{4}$ Centre for Planetary Health and Food Security, Griffith University, Nathan, QLD, Australia. ${ }^{5}$ Department of Veterinary Medicine, University of Cambridge, Cambridge, UK.

${ }^{6}$ National Institute of Allergy and Infectious Diseases, Hamilton, MT, USA.

${ }^{7}$ Department of Microbiology and Immunology, College of Veterinary Medicine, Cornell University, Ithaca, NY, USA.

${ }^{8}$ Department of Biology, Center for Infectious Disease Dynamics, Pennsylvania State University, University Park, PA, USA.

${ }^{9}$ Department of Ecology and Evolution, University of Chicago, Chicago, IL, USA. ${ }^{10}$ Department of Microbiology, Immunology, and Pathology, College of Veterinary

Medicine and Biomedical Sciences, Colorado State University, Fort Collins, CO, USA.

${ }^{11}$ Department of Ecology, Montana State University, Bozeman, MT, USA.

${ }^{12}$ These authors contributed equally: Manuel Ruiz-Aravena, Clifton McKee.
}

subgenera of Alphacoronavirus and Betacoronavirus (FIG. 3). The apparent absence of coronaviruses in particular bat taxa is most likely due to insufficient sampling rather than true absence ${ }^{16}$.

Sequence similarity among viruses in different hosts has been used to infer viral origins. Viruses with high sequence similarity to the three recently emerged human coronaviruses - SARS-CoV, SARS-CoV-2 and MERS-CoV - have all been identified in bats (FICS 2,3). Separate clades of coronaviruses from rhinolophid bats show up to $92 \%$ sequence identity to SARS- $\mathrm{CoV}^{17}$ and up to $96 \%$ sequence identity to SARS-CoV-2 (REF. ${ }^{10}$ ) at the genome level. Additional SARS-related coronaviruses (SARSr-CoVs) have been detected in hipposiderid and molossid bats in Africa, Asia and Europe (Supplementary Table 1), and it is widely accepted that bats are the natural reservoir of SARSr-CoVs ${ }^{18-20}$. Similarly, coronaviruses from vespertilionid bats show up to $86.5 \%$ sequence identity to MERS-CoV at the genome level ${ }^{16}$, and related coronaviruses circulate in bats within the families Nycteridae, Emballonuridae and Molossidae in Africa, Europe, North America and Asia (Supplementary Table 1). The absence of related sequences in other animals suggests that a progenitor of MERS-CoV spilled over from bats into dromedary camels (Camelus dromedarius) ${ }^{21}$. Viruses related to the endemic human coronaviruses HCoV-229E (Duvinacovirus) and HCoV-NL63 (Setracovirus) have been detected in Africa and South-East Asia in hipposiderid bats (sharing up to $91 \%$ sequence identity at the genome level with HCoV-229E) and rhinonycterid bats (sharing up to $78 \%$ sequence identity across the genome with HCoV-NL63) (FICS 2,3; Supplementary data; Supplementary Table 1).

The wide distribution and high diversity of coronaviruses in bats is most likely the result of a long coevolutionary history. Some coronavirus groups seem to be exclusively associated with specific taxonomic groups of bats. For instance, the subgenus Nobecovirus has been detected mostly in Old World fruit bats (Pteropodidae). Further understanding of the biogeography of bats and their coronaviruses would reveal key geographical areas of risk as well as bat coronavirus dynamics.

Infection and response in bats. Frequently, reservoir hosts of zoonoses appear tolerant of the pathogenic effects of infection, whereas humans experience severe disease ${ }^{22}$. Whether bat species are universally tolerant of coronavirus infection remains unclear as few experimental coronavirus challenge studies involving bats have been performed, the putative natural reservoir bat species was often not used and it is unclear whether the infectious doses resembled those of natural exposures (TABLE 1; Supplementary Table 2). In bats experimentally infected with coronaviruses, some individuals have shown mild tissue damage, including rhinitis ${ }^{23,24}$ and interstitial pneumonia ${ }^{24}$, with virus or viral RNA detected in the respiratory tract and/or intestines; however, infected animals did not exhibit evident clinical signs of infection.

Little is known about the immune responses of bats to coronavirus infections, both adaptive and innate. 
a

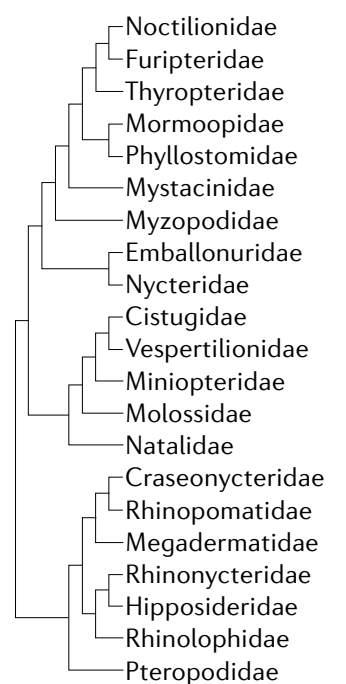

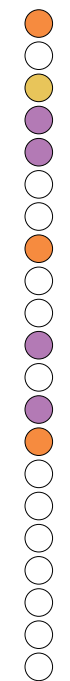
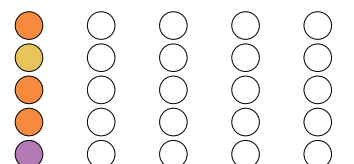

b

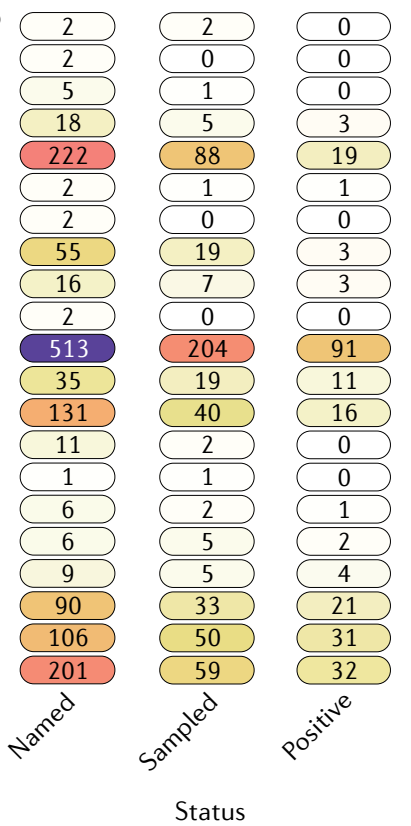

Family present, sampled, CoVs detected

Family present, sampled, no CoVs detected

Family present, not sampled

Family not present

Fig. 1 | Geographical and taxonomic distribution of reported bat hosts of coronaviruses. a | Biogeographical patterns of bat families, sampling and coronavirus host status. b | Bat taxonomic diversity and coronavirus testing results. Data were compiled from field studies involving sequencing of coronaviruses in wild bats. A list of all reported bat coronavirus hosts based on the reviewed studies can be found in Supplementary Table 1 and Supplementary data. 'Named' refers to the number of taxonomically described bat species per family based on the expert-curated Bat Species of the World database. Bat Species of the World database. CoVs, coronaviruses.

While serological studies have been used for surveillance of pathogens such as Nipah virus, Marburg virus and Ebola virus in bats, little serological information is available for most coronaviruses in bats, although antibody responses may be relatively weak and transient. There are even fewer data on coronavirus-specific innate immune responses, or whether those might render a robust antibody response less important. For example, seroconversion of bats after challenge with coronaviruses is not always observed ${ }^{24,25}$. In experimental challenges of Egyptian fruit bats (Rousettus aegyptiacus) with bat SARS-like coronavirus WIV1 (originally isolated from a Chinese rufous horseshoe bat, Rhinolophus sinicus), evidence of viral replication was limited, no bats showed obvious signs of disease and only 2 of 12 individuals seroconverted (measured by enzyme-linked immunosorbent assay), although no neutralizing antibodies were detected $^{25}$. When Jamaican fruit bats (Artibeus jamaicensis) were challenged with a human isolate of MERS-CoV, only one of ten bats produced neutralizing antibodies, and moderate pathological changes in the lungs were present and innate antiviral genes (MX1, CCL5 and ISG56) were modestly upregulated ${ }^{24}$. It is unclear whether these apparently poor antibody responses result from weak infection of the bat species challenged perhaps due to suppression of virus replication by the innate immune response - or naturally low viral capacity to infect the host species. In-depth seroprevalence studies are generally key to understanding the epidemiological history of the population ${ }^{26}$, but the variability in adaptive humoral responses in bats suggests caution is required in the interpretation of serological data, especially at the individual level. For example, limited humoral responses may make it difficult to use serology to identify infections by certain pathogens.

In bats, coronaviruses may have tropism for the respiratory tract and the gastrointestinal tract. The highest loads of MERS-CoV RNA and infectious virus in experimentally infected Jamaican fruit bats were detected in the respiratory tract, with less virus in the intestines and internal organs ${ }^{24}$. Intranasal inoculation of Egyptian fruit bats with SARS-CoV-2 resulted in transient respiratory infections, with the highest viral loads in the respiratory tract on day 4 after inoculation, whereas oral and faecal viral shedding was observed for up to 12 days $^{23}$. Long periods of viral shedding in faeces of 3-11 weeks have been reported in wild bats (Myotis macropus), supporting the importance of a potential faecaloral route of transmission; in that field study, potentially persistent infections could not be distinguished from reinfections ${ }^{27}$. Viral RNA was also found in the intestines of Leschenault's rousette (Rousettus leschenaultii) bats orally inoculated with a betacoronavirus isolated from a lesser short-nosed fruit bat (Cynopterus brachyotis), but no infectious virus was isolated from recipient bats nor was disease observed, suggesting the species is 

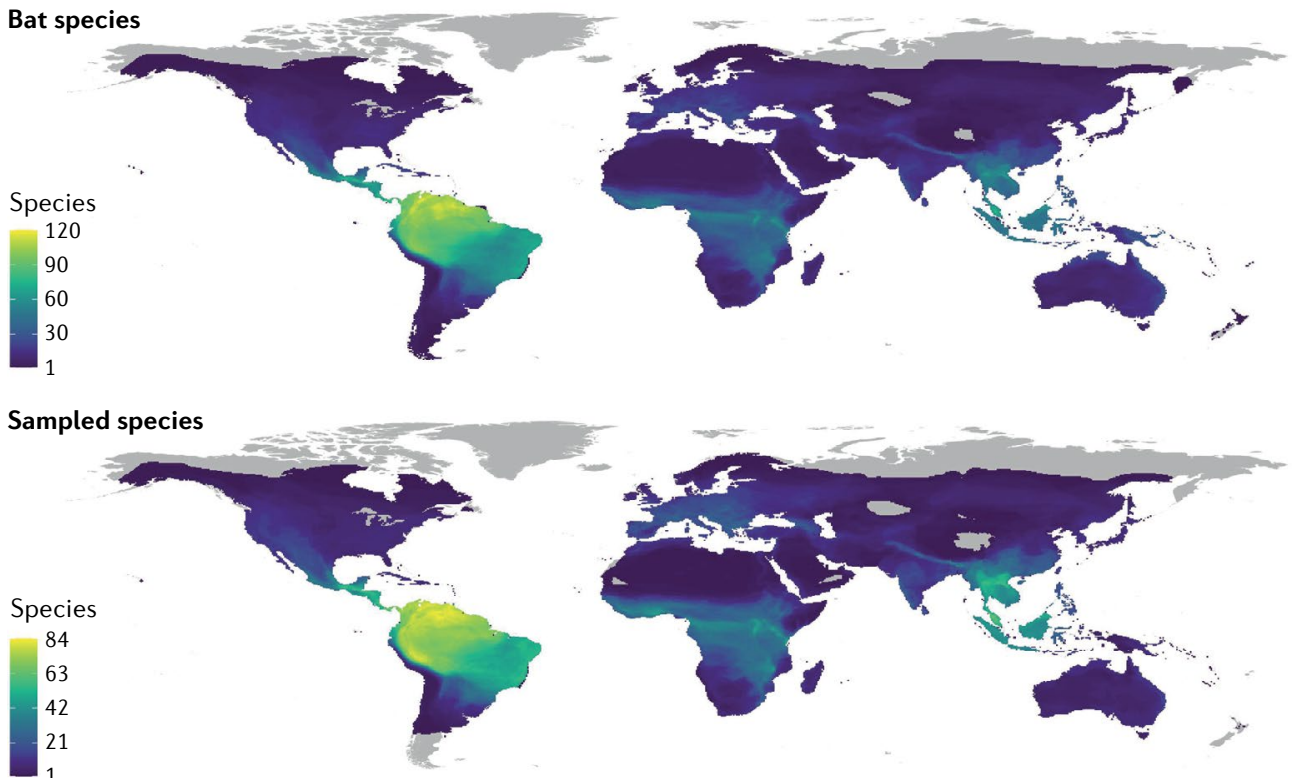

Coronavirus hosts (alphacoronavirus and betacoronavirus)

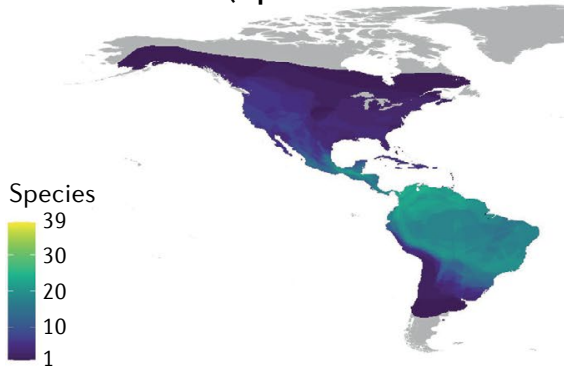

Key coronavirus subgenus hosts

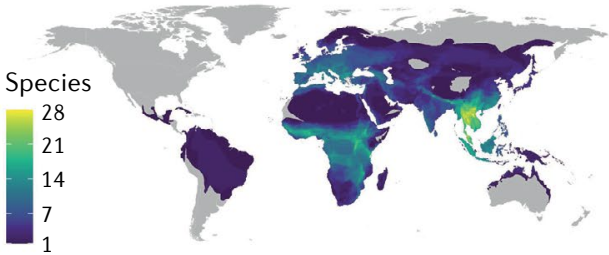

Hibecovirus hosts (betacoronavirus)

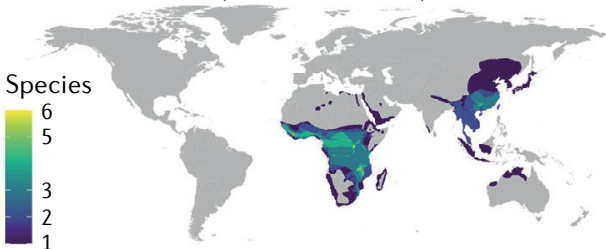

Nobecovirus hosts (betacoronavirus)

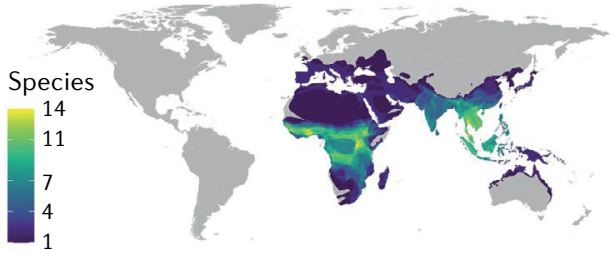

Sarbecovirus hosts (betacoronavirus)

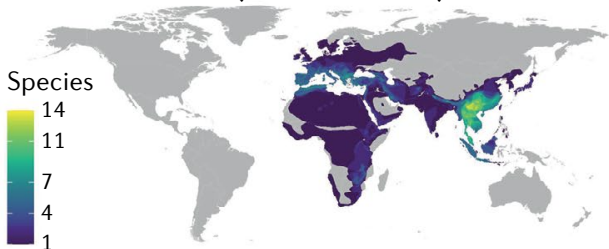

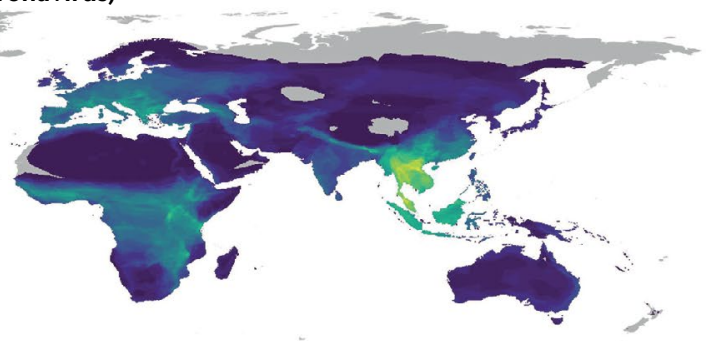

Duvinacovirus hosts (alphacoronavirus)

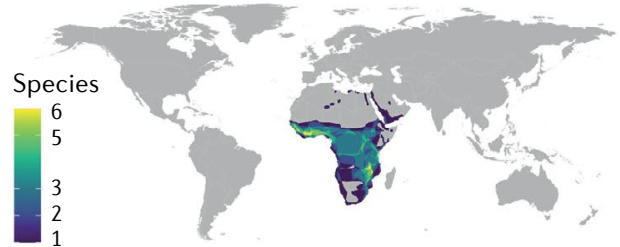

Merbecovirus hosts (betacoronavirus)

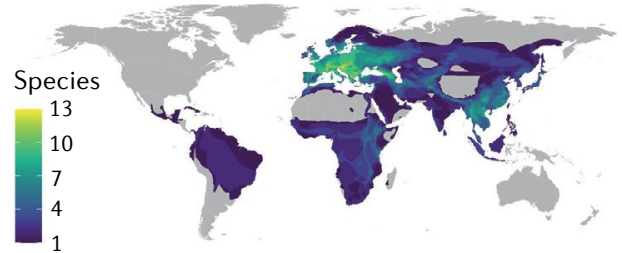

Rhinacovirus hosts (alphacoronavirus)

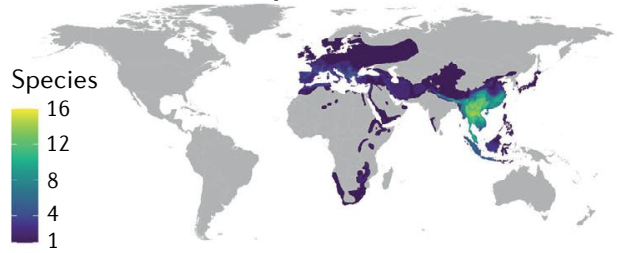

Setracovirus hosts (alphacoronavirus)

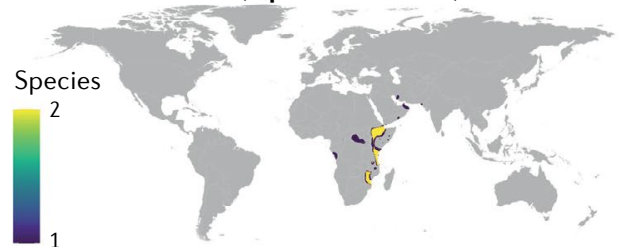


4 Fig. 2 | Geographical distribution of reported bat hosts of coronaviruses. Data on bat hosts were compiled from field studies involving sequencing of coronaviruses in wild bats. Where phylogenetic analysis was included in studies, key Alphacoronavirus and Betacoronavirus subgenera of bats associated with human or domestic animal infections or well characterized in bats (for example, Hibecovirus and Nobecovirus) are summarized (see Supplementary data). Geographical ranges of reported bat host species for any coronaviruses or key subgenera were obtained from the International Union for Conservation of Nature (IUCN). The plots display the number of bat species based on overlapping geographical ranges. The plots of bat species include 1,317 species with IUCN range data as of September 2021. Patterns in the left-hand maps indicate that sampling of bat species largely reflects the biogeographical patterns of bat diversity, with hotspots in Central America, South America, equatorial Africa and South-East Asia. However, hotspots of bat hosts of coronaviruses display important differences: lower than expected diversity of hosts in South America and higher diversity of hosts in South-East Asia. Although biological differences in bat coronavirus interactions with certain bat families (for example, Rhinolophidae) might explain some of these patterns, small sample sizes in some species in the Americas and more intensive sampling in China and South-East Asia likely contribute as well.

Body condition

Proxy for nutritional status of an organism. Commonly measured as the body mass above or below that predicted as a function of skeletal size.

\section{Superspreading}

Transmission event in which one infected host generates several new infections above the average in the population.

Aerosolization

Physical process by which a pathogen stabilizes in particles small enough to be transported through air currents. not a competent host for this virus ${ }^{28}$. Further evidence of tropism of coronaviruses for the gastrointestinal and respiratory systems of bats comes from field studies in which coronaviruses have been detected in intestines of little brown bats (Myotis lucifugus) ${ }^{29}$. Additionally, expression of cell receptors used by multiple coronaviruses was high in both the gastrointestinal system and the respiratory system in fruit bats, whereas it was present only in the intestines of insectivorous bats ${ }^{30}$.

Many coronavirus infection studies have used bat cell lines (TABLE 1; Supplementary Table 2), and mostly focused on viral receptor binding, cell entry and infection, providing insights into the ability of specific coronaviruses to infect cells from different hosts. Although these studies may provide insights into the spillover potential of specific viruses, they likely provide limited insight into bat susceptibility at the organismal level and studies making such inferences should be interpreted with caution. For example, a study that used big brown bat (Eptesicus fuscus) kidney cells showed that innate antiviral genes, specifically the interferon- $\beta$ gene, were not repressed by MERS-CoV ${ }^{31}$, and long-term persistent MERS-CoV infections were achieved in these big brown bat cells. However, whether those viruses cause persistent infections in bats cannot be predicted without infections of live animals.

Circulation in bat populations. The prevalence of coronaviruses - as estimated by the proportion of bats with detectable viral RNA in faeces or in faecal or oral swabs shows high temporal and spatial variability (FIG. 4). Overall, shedding of coronaviruses tends to peak during summer or autumn in Australia and China ${ }^{32-35}$, dry seasons in central Africa and Asia ${ }^{16}$, and wet seasons in western or south-eastern Africa ${ }^{36,37}$. Although trends differ among studies, seasonal variations are consistently observed, pointing to potential mechanistic roles of resource availability, reproductive cycles and host behaviour.

Although nutritional stress during periods of resource scarcity has been implicated in the shedding of other bat viruses ${ }^{38,39}$, their influence on coronavirus shedding is unclear, with effects differing by bat species and virus variants. In Thailand, increased prevalence of both alphacoronaviruses and betacoronaviruses was associated with low body condition in Lyle's flying foxes (Pteropus lylei $)^{40}$. In the Chinese rufous horseshoe bat (Rhinolophus sinicus), low body condition was associated with increased shedding of one variant of Sarbecovirus (SARS-related Rhinolophus bat coronavirus (SARSr-Rh-BatCoV)), but not of another Rhinolophus coronavirus (Rh-BatCoV HKU2) ${ }^{41}$. In Ghana, infection by the alphacoronavirus Alpha229E-CoV correlated with low body condition in Noack's roundleaf bat (Hipposideros cf. ruber) but not in the Aba roundleaf bat (Hipposideros abae).

Colony size, density and composition could also affect virus prevalence by changing transmission rates both within and between roosts. Roost composition affects viral circulation as multiple bat species often roost together and viral infection of different bat hosts will depend on combinations of the host species and the viral strains involved. For example, mixed-species roosts in Yunnan province, China, exhibited greater prevalence of SARSr-CoVs when Rhinolophus sinicus, a primary host of SARSr-CoVs, was more abundant in the roost than other species. In the same roost, the lowest prevalence was detected when Aselliscus stoliczkanus was the most abundant bat species ${ }^{34}$. Roost size and location, including whether the roosts are in caves, seem to affect the chance of spillover of viruses between host species - likely due to close physical contact in dense roosts ${ }^{42}$. In addition to heterogeneity in competence among host species, heterogeneity in shedding and infectivity (for example, superspreading and aerosolization capacity) is a feature of coronavirus infections in humans ${ }^{43}$. However, the extent to which this individual-level heterogeneity explains coronavirus transmission in bats, variation in prevalence among roosts and the risk of spillover is unknown.

Reproductive cycles also influence prevalence and transmission of viruses in bat colonies by affecting patterns of behaviour and physiological susceptibility. Increased social contacts among different species of Chinese horseshoe bats during the mating season and when feeding after hibernation might explain peaks of SARSr-Rh-BatCoV and Rh-BatCoV HKU2 infection in spring ${ }^{41}$. In species that form maternal roosts, for example, increases in group size coincide with pregnancy and gestation, during which time inflammatory immune responses are downregulated, potentially facilitating infection and shedding ${ }^{44,45}$. Periparturient stress may also affect viral shedding, as observed in greater horseshoe bats (Rhinolophus ferrumequinum), Geoffroy's bats (Myotis emarginatus) ${ }^{46}$ and mouse-eared bat (Myotis myotis $)^{47}$, in which both the proportion of bats shedding virus and viral concentrations increased after parturition. Similarly, in relation to reproductive cycles, high prevalence and concentration of coronaviruses detected in Chinese horseshoe bats (predominantly Rhinolophus sinicus) during September and October, are attributed to increases in the number of susceptible juveniles ${ }^{32,34}$. Cross-sectional surveys of multiple bat species report higher infection rates or viral shedding in juveniles and subadults, supporting age-related differences in susceptibility and competence of infection, consistently across species $^{16,40,48,49}$. Further field studies of multiple species across East Africa found that in both age categories, 
shedding was highest during weaning ${ }^{49}$ - timing that relates to behavioural changes, physiological stress and potential waning of maternal immunity.

Although some associations have been seen between seasonal factors and circulation of coronaviruses in bats, our understanding of the mechanisms is currently insufficient to predict dynamics of shedding (FIG. 4). Many of the associations with seasonal factors may be coincidental rather than causal, explaining the lack of consistent patterns across taxa and geographies. Small sample sizes and limited temporal resolution are common issues that hamper statistical power. We could vastly improve our understanding of coronavirus dynamics across species

\section{Table 1 | Summary of $\mathbf{2 1 4}$ original studies on coronaviruses in bats}

\begin{tabular}{|c|c|c|}
\hline Study type ${ }^{a}$ & Number of studies & Overview \\
\hline \multirow[t]{3}{*}{ Experimental } & \multirow[t]{2}{*}{ Bat cell lines: 29} & $\begin{array}{l}\text { Target cells: brain, embryo, } \\
\text { intestine, kidney, lung }\end{array}$ \\
\hline & & $\begin{array}{l}\text { Tested viruses: multiple bat } \\
\text { SARS-related CoVs, BatCoV } \\
\text { HKU4, BatCoV HKU9, HCoV-229E, } \\
\text { HCoV-NL63, MERS-CoV, PEDV, } \\
\text { Ro-BatCoV GCCDC1, SADS-CoV, } \\
\text { SARS-CoV, SARS-CoV-2, } \\
\text { Scotophilus BatCoV 512, TGEV }\end{array}$ \\
\hline & Live bats: 6 & $\begin{array}{l}\text { Tested hosts and viruses: } \\
\text { Artibeus jamaicensis (MERS-CoV), } \\
\text { Eptesicus fuscus (SARS-CoV-2), } \\
\text { Myotis lucifugus (Myl-CoV), } \\
\text { Rousettus leschenaultii (BatCoV } \\
\text { HKU9), Rousettus aegyptiacus } \\
\text { (bat SARS-like CoV WIV1, } \\
\text { SARS-CoV-2) }\end{array}$ \\
\hline \multirow[t]{3}{*}{ Longitudinal } & \multirow[t]{3}{*}{14} & $\begin{array}{l}\text { Countries: Australia, China, } \\
\text { Denmark, Germany, Malaysia, } \\
\text { Singapore, South Korea, Thailand } \\
(n=8)\end{array}$ \\
\hline & & $\begin{array}{l}\text { Serially sampled bat families: } \\
\text { Pteropodidae, Hipposideridae, } \\
\text { Vespertillionidae, Rhinolophidae } \\
(n=4)\end{array}$ \\
\hline & & $\begin{array}{l}\text { Serially sampled species: } \\
\text { Eonycteris spelaea, Hipposideros } \\
\text { cervinus, Myotis daubentonii, } \\
\text { Myotis macropus, Myotis myotis, } \\
\text { Pteropus lylei, Rhinolophus sinicus, } \\
\text { Rousettus leschenaultii }(n=8)\end{array}$ \\
\hline \multirow[t]{7}{*}{ Surveys } & Cross-sectional, intraspecies: 14 & \multirow{2}{*}{$\begin{array}{l}\text { Sampled countries: primarily in } \\
\text { Asia, Africa and Europe; fewer in } \\
\text { the Americas or Oceania }(n=69)\end{array}$} \\
\hline & Cross-sectional, interspecies: 123 & \\
\hline & $\begin{array}{l}\text { CoV detection and sequencing } \\
\text { only: } 29\end{array}$ & \multirow{2}{*}{$\begin{array}{l}\text { Sampled bat families: all bat } \\
\text { families have been sampled at } \\
\text { least once except Cistugidae, } \\
\text { Furipteridae and Myzopodidae } \\
(n=18)\end{array}$} \\
\hline & \multirow[t]{4}{*}{ Multipathogen detection: 36} & \\
\hline & & Positive bat families: 14 \\
\hline & & Sampled bat species: 543 \\
\hline & & Positive bat species: 238 \\
\hline \multicolumn{3}{|c|}{$\begin{array}{l}\text { BatCoV, bat coronavirus; CoV, coronavirus; HCoV, human coronavirus; MERS-CoV, Middle } \\
\text { East respiratory syndrome coronavirus; Myl-CoV, Myotis lucifugus coronavirus; PEDV, porcine } \\
\text { epidemic diarrhoea virus; Ro-BatCoV, Rousettus bat coronavirus; SADS-CoV, swine acute } \\
\text { diarrhoea syndrome coronavirus; SARS, severe acute respiratory syndrome; SARS-CoV, severe } \\
\text { acute respiratory syndrome coronavirus; TGEV transmissible gastroenteritis virus. }{ }^{2} \text { Study types } \\
\text { were not exclusive, so a study may fit into multiple types depending on the sampling approach } \\
\text { and analytical methods. More details are provided in Supplementary Table 2, and all classified } \\
\text { studies can be found in Supplementary data. }\end{array}$} \\
\hline
\end{tabular}

$\begin{array}{ll}\text { Study type } & \text { Number of studies } \\ \text { Experimental } & \text { Bat cell lines: } 29\end{array}$

Live bats: 6

Cross-sectional, intraspecies: 14 only: 29

Multipathogen detection: 36
Target cells: brain, embryo,

intestine, kidney, lung

HKU4, BatCoV HKU9, HCoV-229E, COV-NL63, MERS-CoV PEDV,

SARS-CoV, SARS-CoV-2

cotophilus BatCoV 512, TGEV

Eptesicus fuscus (SARS-CoV-2), Myotis lucifugus (Myl-CoV),

Rousettus leschenaultii (BatCoV

9), Rousettus aegyptiacus

SARS-CoV-2

Countries: Australia, China,

Denmark, Germany, Malaysia, Singapore, South Korea, Thailand $(n=8)$ espertillionidae, Rhinolophidae Pteropus lylei, Rhinolophus sinicus, Rousettus leschenaultii $(n=8)$

Sampled countries: primarily in Asia, Africa and Europe; fewer in Sampled bat families: all bat families have been sampled at least once except Cistugidae, Furipteridae and Myzopodidae $(n=18)$

Positive bat families: 14

Sampled bat species: 543

Positive bat species: 238

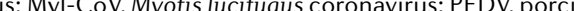
: SARS, severe acute respiratory syndrome: SARS-CoV, severe (transmissible gastroenteritis virus a Study types and analytical methods. More details are provided in Supplementary Table 2, and all classified studies can be found in Supplementary data. through coordinated and systematic approaches to field studies that sample individual bats, paired with experimental inoculation and transmission studies, and then integrated with modelling studies aimed at assessing the importance of factors driving infection ${ }^{50}$.

Co-infections in bats. Co-infections with multiple pathogens can influence transmission to conspecifics and to spillover hosts. Cross-protective immunity from infection by related pathogens might reduce susceptibility or transmission, whereas trade-offs in immune response to one pathogen might increase susceptibility and facilitate transmission of another ${ }^{39,51}$. Co-infection of bats with multiple coronaviruses at the same time, or co-circulation of multiple virus genotypes within a roost, might result in interactions that affect the timing, location and intensity of virus shedding, as has been described in other viral families ${ }^{39}$. As with other putative drivers, the incidence and effects of coronavirus co-infections on transmission dynamics in bats are not well understood. Co-infections by two coronavirus species ${ }^{36,41,52-57}$ and by coronaviruses and viruses from other families, including adenoviruse $^{58,59}$, astroviruses ${ }^{58,60-62}$, herpesviruses ${ }^{58}$ and paramyxoviruses ${ }^{63}$, have been described and are likely common. Cases of co-infections (by detection of viral RNA) involving coronaviruses range from $0.2 \%$ to $34.2 \%$ in wild bats ${ }^{36,52-56}$ and are as high as $73 \%$ in captive bats ${ }^{64}$, while up to $88 \%$ of virus-positive samples contained multiple viral families ${ }^{60}$. Frequent co-infection has additional important consequences because coronaviruses recombine frequently, providing an opportunity for the emergence of new variants with altered properties, including host ranges.

A few studies have examined ecological interactions between co-infections of coronaviruses and non-viral pathogens, including whether they are competitive, synergistic or neutral. For instance, a 60 -fold increase in coronavirus (Myotis lucifugus coronavirus) RNA was observed in the intestines of bats (Myotis lucifugus) co-infected with the fungus that causes white nose syndrome (Pseudogymnoascus destructans) ${ }^{65}$. Systemic downregulation of antiviral immune responses due to Pseudogymnoascus destructans infection was suggested as the cause of increased coronavirus replication. Similarly, ectoparasite loads have been associated with coronavirus infection; infection with Alpha229E-CoV almost doubled the risk of infection by BetaBI-CoV in Noack's roundleaf bat but also correlated positively with loads of streblid flies, mites and nycteribiid flies ${ }^{36}$. Longitudinal studies tracking the health and immune status of individual bats, including co-infections, are crucial to understanding the dynamics of bat viruses.

\section{Molecular evolution and host range}

Viral genetic diversity and evolution. Coronaviruses have the largest genome among the RNA viruses, and are subject to both mutation and recombination ${ }^{66}$. These processes generate genetic diversity, some of which may introduce new properties, including altered host ranges, along with increases in the ability to spread in the new host. Approximately two-thirds of the coronavirus genome encodes an RNA-dependent RNA polymerase 


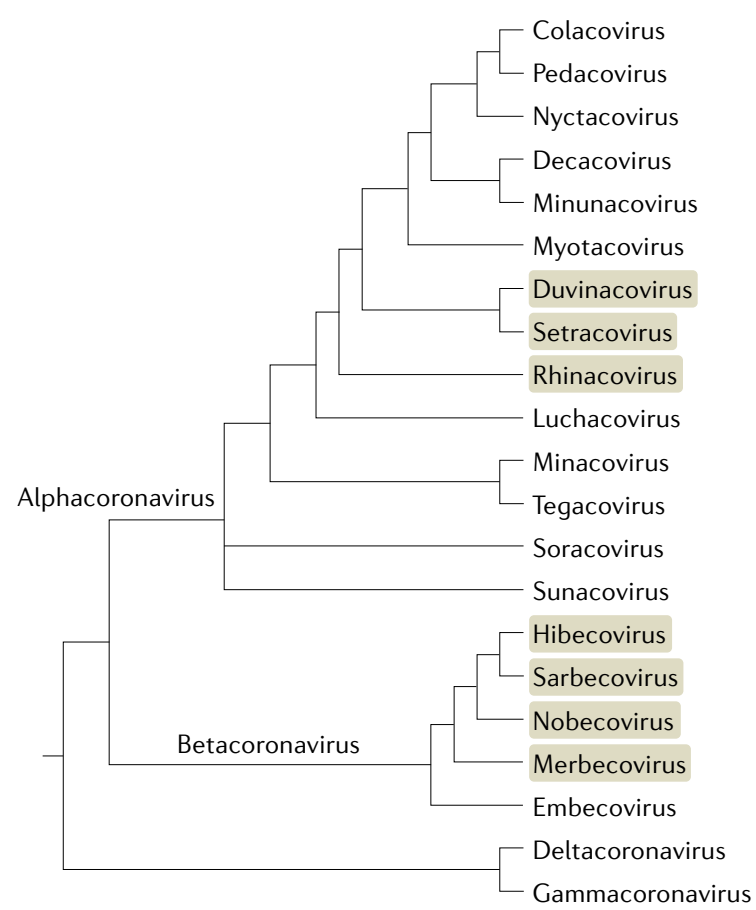

Subgenomic RNAs

Fragments of RNA smaller than the full genome size generated during replication of coronaviruses in a host cell. virus.

\begin{tabular}{|c|c|c|}
\hline Genus/subgenus & Notable virus species & Hosts species \\
\hline \multicolumn{3}{|l|}{ Alphacoronavirus } \\
\hline Colacovirus & Myl-CoV & Bats (Vespertilionidae) \\
\hline Pedacovirus & PEDV & Bats (Vespertilionidae), pigs \\
\hline Nyctacovirus & & Bats (Vespertilionidae) \\
\hline Decacovirus & & Bats (Hipposideridae, Rhinolophidae) \\
\hline Minunacovirus & & Bats (Miniopteridae) \\
\hline Myotacovirus & & Bats (Vespertilionidae) \\
\hline Duvinacovirus & HCoV-229E & $\begin{array}{l}\text { Bats (Hipposideridae), dromedary } \\
\text { camels, alpacas, humans }\end{array}$ \\
\hline Setracovirus & HCoV-NL63 & Bats (Rhinonycteridae), humans \\
\hline Rhinacovirus & SADS-CoV & Bats (Rhinolophidae), pigs \\
\hline Luchacovirus & & Rodents (Muridae, Cricetidae) \\
\hline Minacovirus & & Ferrets, minks \\
\hline Tegacovirus & CCoV, FCoV, TGEV & Cats, dogs, pigs \\
\hline Soracovirus & & Shrews (Suncus murinus) \\
\hline Sunacovirus & & Shrews (Sorex araneus) \\
\hline \multicolumn{3}{|l|}{ Betacoronavirus } \\
\hline Hibecovirus & & Bats (Hipposideridae) \\
\hline Sarbecovirus & SARS-CoV, SARS-CoV-2 & $\begin{array}{l}\text { Bats (Rhinolophidae), Malayan } \\
\text { pangolins, carnivores (Canidae, Felidae, } \\
\text { Mustelidae, Viverridae), humans }\end{array}$ \\
\hline Nobecovirus & & Bats (Pteropodidae) \\
\hline Merbecovirus & MERS-CoV & $\begin{array}{l}\text { Bats (Vespertilionidae), } \\
\text { dromedary camels, humans }\end{array}$ \\
\hline Embecovirus & $\begin{array}{l}\text { BCoV, CRCoV, } \\
\text { HCoV-OC } 43, \\
\text { HCoV-HKU1, } \\
\text { MCoV }\end{array}$ & $\begin{array}{l}\text { Rodents (Muridae, Cricetidae), dogs, } \\
\text { rabbits, cattle, horses, pigs, sable } \\
\text { antelopes, dromedary camels, } \\
\text { giraffes, humans }\end{array}$ \\
\hline Deltacoronavirus & PorCoV-HKU15 & Birds, pigs \\
\hline Gammacoronavirus & IBV & Birds, cetaceans \\
\hline
\end{tabular}

Fig. 3 | Coronavirus taxonomy and host distribution. The proposed phylogeny has been compiled from analyses of full genomes and/or gene segments. Branch lengths do not reflect evolutionary distance between taxa and are drawn only to clearly illustrate relationships between and within genera. The distribution of bat species hosting highlighted subgenera is given in FIG. 2. The associated table summarizes a selection of important pathogenic virus species within genera and the host species or taxa with reported infections of a virus within a genus. $\mathrm{BCoV}$, bovine coronavirus; $\mathrm{CCoV}$, canine coronavirus; $\mathrm{CRCoV}$, canine respiratory coronavirus; $\mathrm{FCoV}$, feline coronavirus; $\mathrm{HCoV}$, human coronavirus; IBV, infectious bronchitis virus (avian coronavirus); MCoV, murine coronavirus; MERS, Middle East respiratory syndrome; Myl-CoV, Myotis lucifugus coronavirus; PEDV, porcine epidemic diarrhoea virus: PorCoV, porcine coronavirus; SADS-CoV, swine acute diarrhoea syndrome coronavirus; SARS-CoV, severe acute respiratory syndrome coronavirus; TGEV, transmissible gastroenteritis

and other non-structural proteins required for replication, while the remaining third encodes four structural proteins - the spike, envelope, membrane and nucleocapsid proteins - as well as accessory proteins ${ }^{67}$. The genomes of coronaviruses replicate via the RNA-dependent RNA polymerase, which is generally error-prone, resulting in mutations during replication ${ }^{68,69}$. However, the three largest viral families in the order Nidovirales - Coronaviridae, Roniviridae and Mesoniviridae - all encode a $3^{\prime}-5^{\prime}$ exoribonuclease that improves their RNA replication fidelity, which may be necessary for maintaining sufficient fitness in the large genome $\mathrm{e}^{70-73}$. The activity of the exoribonuclease might differ in different hosts, modulating the level of sequence variation. Replication in different host species may therefore present heterogeneities in their sequence variation, which may influence the emergence of new variants ${ }^{16,20,74-76}$.

Recombination of large coronavirus genomes is common; recombination creates additional genetic diversity, expands viral evolution and increases the potential for shifts in cell tropism, host range ${ }^{66}$ and pathogenicity ${ }^{77}$. During coronavirus replication in the host cell, subgenomic RNAs are generated, which result from the polymerase jumping to new positions in the template genome. This may facilitate recombination of genes from different coronavirus lineages during co-infection of a host cell when the RNA-dependent RNA polymerase 'jumps' from one RNA template molecule to another one that may come from a different viral genome $^{66,78}$. These recombination processes have been implicated in the cross-species emergence of numerous novel coronaviruses, including murine coronavirus ${ }^{79}$, transmissible gastroenteritis virus ${ }^{80}$, feline and canine coronaviruses $^{81,82}$, and six of the seven human coronaviruses, $\mathrm{HCoV}-\mathrm{OC} 43\left(\mathrm{REF}^{83}\right), \mathrm{HCoV}-\mathrm{NL} 63\left(\mathrm{REFS}^{8,84}\right)$, HCoV-229E ${ }^{8}$, HCoV-HKU1 (REF. ${ }^{85}$ ), SARS-CoV ${ }^{86,87}$ and MERS-CoV ${ }^{88}$. Interestingly, evidence supports recombination of coronavirus genomes possibly happening also with RNA viruses from the family Reoviridae ${ }^{89}$. However, how frequent interfamily recombination events may happen and their consequences for evolution of zoonotic potential are unknown.

Mutation, recombination and host competence for infection and co-infection will have generated the current 

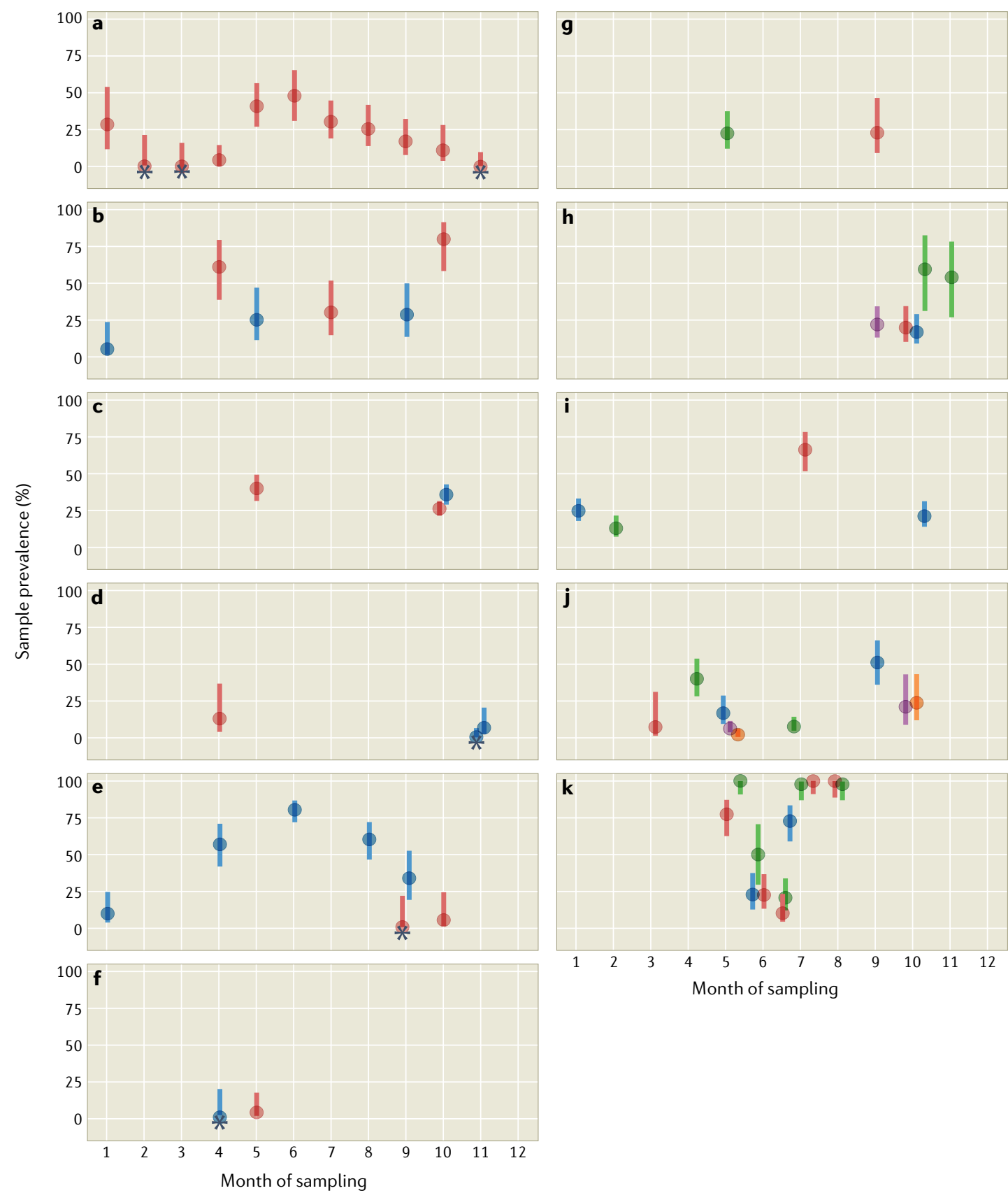

Month of sampling

Fig. 4 | Prevalence of detection of bat coronaviruses in field samples. Data were obtained from published studies that included two or more sampling events with at least ten samples collected and that reported the virological status of samples (positive and negative). While the data show that prevalence varies in space and time and by bat species (each plot), few studies provide insights into the drivers of prevalence. No field studies have yet combined longitudinal sampling of individuals with collection of extensive metadata on bat ecology, bat health and environmental conditions. Sampling designs differed across studies. Most studies conducted cross-sectional sampling over multiple years. One field study sampled individual bats at multiple sites over time, although data were pooled across three $\operatorname{sites}^{40}$ (panel a). Other studies sampled the same bat species over time across multiple sites or sampled multiple species and individuals in pooled samples across time within a site. These sampling approaches reflect the purpose of the studies - most were focused on characterizing viral diversity, not infection dynamics. Details are presented in Supplementary information. Each plot represents the prevalence of detections per bat species: Pteropus lylei (panel a ${ }^{40}$; Eonycteris spelaea (panel $\left.\mathbf{b}\right)^{64}$; Rousettus leschenaultii (panel c) ${ }^{158}$; Chaerephon pumilus (panel d $)^{49}$; Eidolon helvum (panel $\left.\mathbf{e}\right)^{49}$; Myonycteris angolensis (panel f $)^{49}$; Rhinolophus cf. clivosus (panel g) $)^{49}$; Myotis daubentonii (panel h) ${ }^{159}$; Rhinolophus sinicus (panel i ${ }^{160}$; Rhinolophus sinicus, Rhinolophus ferrumequinum, Rhinolophus affinis and Aselliscus stoliczkanus (panel j) $)^{34}$; and Myotis myotis (panel k) ${ }^{47}$. Colours in the plots represent different years within the study: year 1, red; year 2, blue; year 3, green; year 4, purple; and year 5 , orange. Black asterisks show sampling events in which no coronavirus was detected. Circles show the mean prevalence, and bars show the $95 \%$ confidence intervals estimated by the Wilson method. 
diversity of coronaviruses, including that seen in bats ${ }^{16,90}$. Some families of bats appear to have coevolved over millions of years with particular subgroups of betacoronaviruses: rhinolophid bats and SARS-related sarbecoviruses, vespertilionid bats and MERS-related merbecoviruses, and pteropodid bats and nobecoviruses (which have not been implicated in zoonosis ${ }^{90}$. Host switching, resulting from successful broad jumps in host range, appear most common in the rhinopholid-Sarbecovirus clade ${ }^{16,20,91}$. Altogether, the variation in the bat coronaviruses may enable them to gain new host and tissue tropisms, and varying transmissibility and infection severity in new hosts. Indeed, once a virus is established in a new host population, evolution is expected to enable selection for lineages with increased fitness in those hosts, including exhibiting higher transmissibility, as observed for SARS-CoV-2 in humans ${ }^{92}$.

Host receptor recognition. The capacity of coronaviruses to enter a host cell is mediated by the spike protein, which supports both binding to the host cell - through its receptor-binding domain (RBD) - and fusion with its membrane ${ }^{67}$. The RBD attaches to host-cell receptors, which are membrane proteins or sialic acids. For example, HCoV-NL63, SARS-CoV and SARS-CoV-2 bind angiotensin-converting enzyme 2 (ACE2), MERS-CoV binds dipeptidyl peptidase 4 (DPP4) and HCoV-229E, canine coronavirus and several porcine and feline coronaviruses bind alanine aminopeptidase (APN), whereas $\mathrm{HCoV}-\mathrm{OC} 43, \mathrm{HCoV}-\mathrm{HKU} 1$ and bovine coronavirus bind $\mathrm{N}$-acetyl-9-O-acetylneuraminic acid ${ }^{93-96}$.

The interaction between the RBD of the coronavirus spike protein and the host receptor can be thought of as a match between a key and a lock, and the specific structures of both the virus RBD and the receptors available on a potential host cell determine, in part, the capacity for infection of different hosts. The functional interactions between the viral protein and the host receptor differ, and the wide host range of several coronaviruses can be explained by the conservation of cell receptor structures across animal species, such is the case of ACE2, $\mathrm{DPP} 4$ and $\mathrm{APN}^{97,98}$. However, small differences in receptor structures can also alter receptor affinity and virus infection efficiency, including both variation in glycosylation profile or amino acid changes ${ }^{93}$. MERS-CoV spike protein, for instance, binds DPP4 of various species of primates, hooved mammals and bats, but not of ferrets and rodents owing to differences in five amino acids in the receptor ${ }^{97}$. Thus, direct coronavirus spillover from bats to other mammals would therefore be regulated by the host-cell receptor structures and viral RBD identity. This is a critical aspect for characterization of zoonotic potential of extant bat coronaviruses; however, for reservoir bat hosts we know relatively little about their receptors or interactions with the viruses. It is currently known from experimental and modelling work that several bat coronaviruses bind to human ACE2 or DPP4; however, structural modelling and biochemical data indicate differences in binding affinity ${ }^{97-99}$ and therefore potential for successful infection of human cells. In some cases, there is only one amino acid residue different between the spike protein RBD and the receptor, suggesting that zoonotic capacity could emerge in a few evolutionary steps.

Isolates of bat coronaviruses are difficult to obtain, and therefore their zoonotic capacity is largely unknown, with many inferences being based on genomic sequences. Among 187 studies that examined coronaviruses in primary samples from wild bats, in less than a quarter, researchers attempted to recover live viruses in one or more cell cultures, yielding only five viral species successfully cultured, including one merbecovirus (Tylonycteris BatCoV HKU4), three sarbecoviruses related to SARS-CoV (WIV1, WIV16 and Rs4874) and one sarbecovirus related to SARS-CoV-2 (BANAL-236), reported in September 2021 (Supplementary data). High-throughput analyses of sequences and carefully controlled cell culture experiments and other experiments are needed to assess spillover and zoonotic potential of the coronavirus variants currently circulating in bats ${ }^{1}$. In silico analysis of cell receptors of humans and other species are useful for initial identification of species that could serve as bridge or reservoir hosts of zoonotic coronaviruses, which could promote optimization of resources for pre-emptive surveillance. For instance, relatively conserved SARS-CoV-2-binding residues in the ACE2 sequences of non-human primates, hooved mammals, felids and cetaceans suggest those species would be susceptible to infection ${ }^{100}$. Several of these predictions have been validated by empirical studies confirming the broad host range of SARS-CoV-2 $\left(\mathrm{REFS}^{98,101}\right)$. However, these studies also classified horseshoe bats, pangolins, minks and ferrets as less likely to be hosts of SARS-CoV-2, yet field and laboratory data have revealed their susceptibility to SARS-CoV-2 or related viruses, highlighting the need for empirical validation of model predictions ${ }^{101,102}$.

It is likely that differences will be seen between in silico analysis and empirical analysis of receptor use by virus species in different hosts. Several studies suggest that the progenitor viruses of SARS-CoV and SARS-CoV-2 may not use the ACE2 receptor in their original bat hosts $^{100,103,104}$. However, this discrepancy could also result from variability in the host receptors with which the viruses have evolved, favouring specific interactions between the RBD and small numbers of receptor residues, so that progenitor viruses are adapted to their specific reservoir ACE2, but not to the human ACE2 (REF. ${ }^{99}$ ), which is used to model many interactions ${ }^{100}$. There is naturally high variation among the ACE2 receptors of bat species ${ }^{105}$, in addition to the high diversity of SARSr-CoVs ${ }^{106}$. New host infection and adaptation likely involves mutations in the viral spike protein, and potentially selection in an intermediate (bridge) host, to enable effective binding and use of human ACE2 and facilitate zoonotic spillover ${ }^{104,107}$. Such a case is supported by the use of human DPP4 by MERS-CoV, where affinity for the human receptor may have emerged by evolution of the virus in dromedary camels, after the initial spillover from bats ${ }^{76}$. Importantly, virus evolution that facilitates binding of human receptors may diminish the binding affinity of a virus for the receptors of the original reservoir hosts ${ }^{108}$, indicating a host shift that may favour sustained human-to-human transmission. Such behaviour is characteristic of pandemic viruses (BOX 1). 


\section{Box 1 | Pathways to pandemic emergence of bat coronaviruses}

While the zoonotic potential of an animal virus depends on its ability and opportunity to infect humans, pandemic potential depends on human-to-human transmissibility, quantified by the virus's reproduction number in humans, $R$. The critical value for $R$ is 1 , the level at which each case replaces itself on average. For subcritical viruses, with $R<1$, transmission chains inevitably die out. For supercritical viruses, with $R>1$, epidemics and pandemics are possible ${ }^{139}$.

Novel viruses with pandemic potential can reach humans by several routes. A virus circulating in bats could have the traits needed for supercritical transmission in humans, by chance or due to evolutionary pressures in the reservoir that fortuitously align with fitness in humans ${ }^{161}$. Such a virus could spill over directly from bats to humans, overcoming ecological barriers of limited spatial overlap and contacts between these species (see the figure, panel a). Alternatively, such a virus could reach humans via a bridge host that has greater contact with humans than the reservoir host, and perhaps also serves to amplify the virus to high levels to increase the probability of initial infection (see the figure, panel b).

Another possibility is that a virus circulating in bats would be subcritical in humans but has opportunity to evolve to become supercritical within a bridge host that shares some key traits (for example, homologous receptor proteins) with humans (see the figure, panel c). A fourth possibility, not depicted here, is that a subcritical virus reaches humans and evolves to become supercritical before its transmission chains die out ${ }^{161}$.

In any of these scenarios, epidemiological factors (and simple chance) will determine whether the supercritical virus goes on to cause an epidemic or a pandemic. Many such introductions die out, particularly if transmission is highly heterogeneous ${ }^{43}$. Reconstruction of outbreak origins hinges on the availability of data and samples from the earliest human cases, and extensive sampling of all host species involved (which often are not known with confidence). Origins and emergence pathways will remain obscure until such data are obtained and analysed.

\section{Coronavirus in bats is supercritical for humans $(R>1)$}

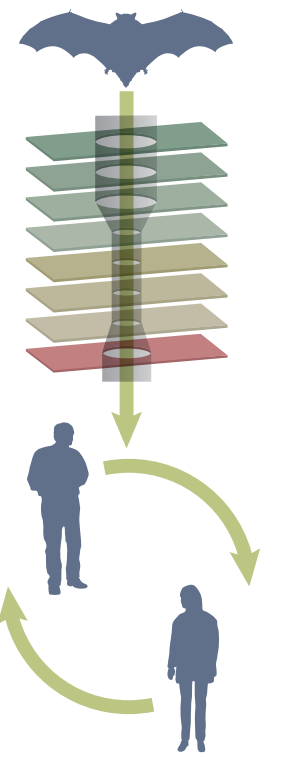

b

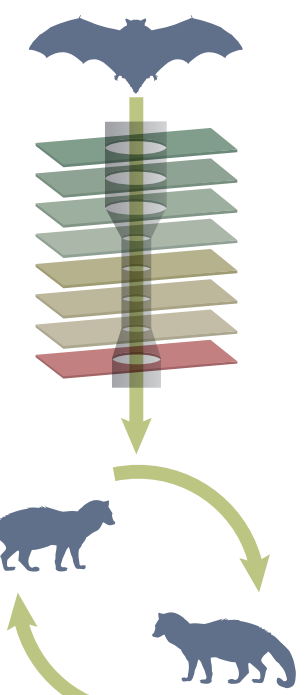

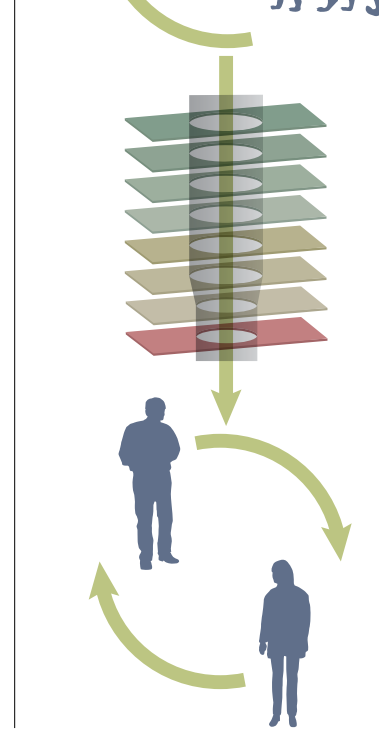

Part a of the figure adapted from REF. ${ }^{140}$, Springer Nature Limited.

Once a coronavirus RBD can bind a receptor on a host cell, the differing distribution of those receptors in different cell types within a host will influence tissue tropism, impacting pathogenesis and transmission. In humans, ACE2 is expressed primarily in epithelial cells of many
Coronavirus in bats is subcritical for humans $(R<1)$
C
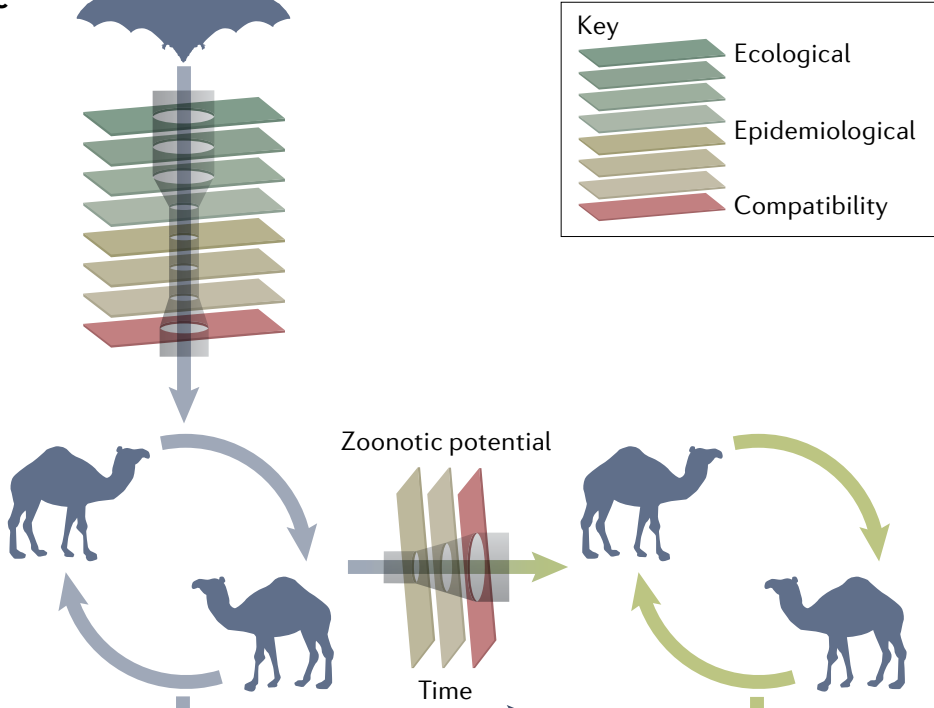
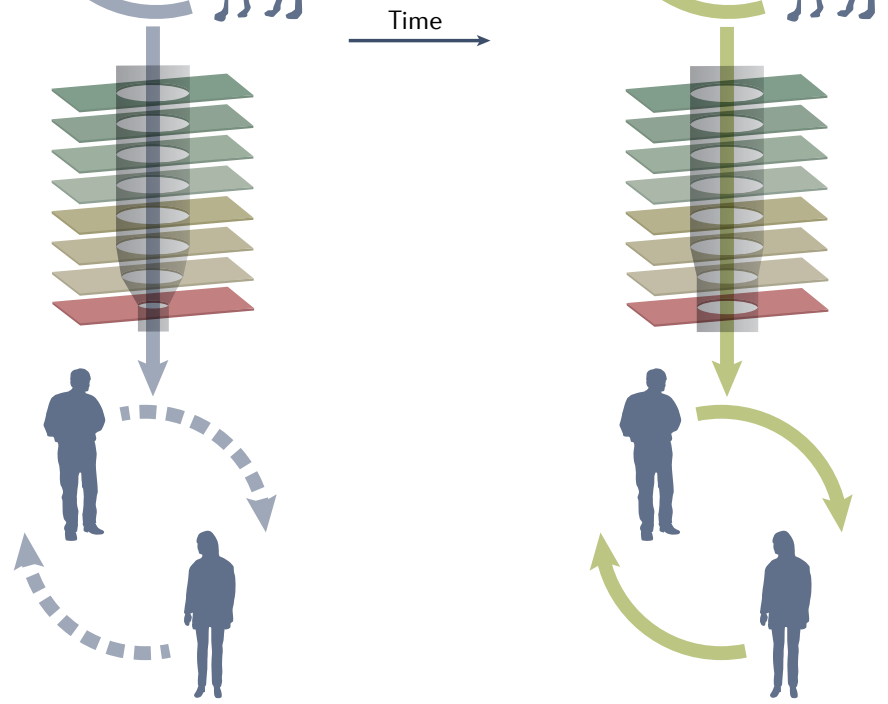

tissues, including the respiratory tract, kidney, heart and digestive tract, consistent with the respiratory and gastrointestinal pathology of SARS-CoV and the multisystemic pathology of SARS-CoV-2 (REFS $\left.{ }^{109,110}\right)$. Although detailed expression profiles of ACE2 in other species are 
lacking, tissue tropism of SARSr-CoVs in several animals is consistent with that in humans. SARSr-CoVs have been detected in the respiratory tract or gastrointestinal tract of Malayan pangolins (Manis javanica) ${ }^{111}$, experimentally inoculated ferrets, felids ${ }^{101,112}$ and non-human primates ${ }^{113}$. Similarly, DPP4 expression in humans, dromedary camels and fruit bats includes epithelial cells of the respiratory and gastrointestinal tracts ${ }^{30}$. In humans, ACE2 expression is particularly high in the upper respiratory tract, while DPP4 is expressed mainly in the lower respiratory tract, potentially contributing to the greater human-to-human transmissibility of SARS-CoV and SARS-CoV-2 compared with MERS-CoV ${ }^{30,114}$. Additionally, DPP4 expression is almost entirely restricted to the intestines in two vespertilionid bats, the putative reservoir of the MERS-CoV progenitor, suggesting different tropism, and potentially transmission routes, between reservoir and spillover hosts ${ }^{30}$. Nevertheless, the detection of coronaviruses in the respiratory and gastrointestinal tracts of experimentally inoculated and wild-caught bats supports the relevance of these two systems for coronavirus infections among diverse host species ${ }^{18,24,29,41,78,90}$.

Host proteases and host range. Besides binding to the cellular receptor, successful infection and replication require several consecutive steps, including entry, replication, potential evasion of the host innate immunity and budding. In addition to the receptors, host proteases are needed to activate (cleave) the virus spike protein to enable entry, and this cleavage may be as important as host receptor binding in determining viral zoonotic potential ${ }^{96,115}$ and potentially human-to-human transmissibility ${ }^{92}$. Spike proteins of coronaviruses have multiple cleavage sites for host proteases, which are cleaved at different stages of the cell infection cycle ${ }^{114}$. Transmembrane serine proteases (such as TMPRSS2), trypsin-like proteases and other cell-surface proteases participate in spike protein cleavage after viral attachment, whereas lysosomal proteases such as cathepsins cleave spike proteins after virus endocytosis. By contrast, the furin proprotein convertase - present in the Golgi apparatus - may be involved in spike protein cleavage during biosynthesis ${ }^{116,117}$. The distribution and activity of these proteases differ among cell types and physiological conditions, therefore influencing tissue tropism and cell entry ${ }^{14,118,119}$. For instance, the respiratory tropism of SARS-CoV might be driven by trypsin-like proteases present in respiratory cells ${ }^{120,121}$.

Therefore, the expression patterns of proteases also directly contribute to host range. For instance, while specific bat proteases cleave the spike proteins of both MERS-CoV and BatCoV HKU4 and enable entry into bat cells, human proteases cleave only the MERS-CoV spike proteins ${ }^{122}$. Understanding how coronavirus spike proteins adapt to being activated by proteases of new hosts (for example, to type, activity and distribution) is essential for predicting the potential for changes in host range and tissue tropism, including spillback infection.

Spillback infection

Also called 'anthropozoonosis'. Transmission of a zoonotic pathogen from humans to animals. the evolution and zoonotic capacity among coronaviruses naturally circulating in bats. However, for zoonotic spillovers to occur, humans must be exposed to the viruses (BOX 1), and this can occur through direct contact with virus excreted from infected bats or bridge hosts, or through other contacts with infected animals, such as slaughtering or butchering. The nature and intensity of the reservoir bat-human interface are critical to determining spillover risk. Human behaviour is a primary determinant of exposure, which may increase contact with bats or with other animals (bridge hosts) that may expose susceptible humans. Little is known about the specific conditions of coronavirus spillovers, but human behaviours that may increase viral exposure include activities such as bat hunting and consumption, guano farming and wildlife trading ${ }^{4,5,123}$. These contacts between humans and bats likely occur under physiologically stressful situations that may increase viral shedding from bats or bridge hosts and exposure of humans - the potential 'patients zero' of a new epidemic. Exposures often occur in rural areas with limited access to health care, so spillovers are detected only when they cause outbreaks or epidemics. For recently emerged human coronaviruses, some factors are known, including roles for bridge hosts in the wildlife trade or among domestic animals; for example, SARS-CoV likely transferred from rhinolophid bats into humans via farmed Himalayan civets (Paguma larvata) ${ }^{78,124,125}$. Alternative pathways of direct human exposure to bat coronaviruses have not been explored thoroughly, and studies that specifically examine human populations at risk of exposure, such as guano farmers, bat hunters and wildlife traders, for evidence of bat coronavirus exposure ${ }^{126}$ and the roles of other species in the transmission chain (BOX 2) are required for effective surveillance of, response to and prevention of future zoonotic coronavirus pandemics.

Reservoir animal-human interface. Human-bat interactions differ widely in space, time, nature and intensity; some bat species rarely encounter humans, whereas

\section{Box 2 | Spillover of coronaviruses in other species}

Coronaviruses have a demonstrated ability for crossspecies transmission involving not only bats and humans, but also transmission to and among other animal species. For example, HKU2, a coronavirus related to a virus detected in rhinolophid bats, caused an outbreak of fatal disease in domestic pigs in China in 2016 (swine acute diarrhoea syndrome coronavirus; FIG. 3) $)^{12}$. In 2017, camel (HKU23) and equine coronaviruses were detected in asymptomatic domestic horses in Saudi Arabia and $\mathrm{Oman}^{162}$. In 2020, chicken, duck, pigeon and goose coronaviruses were observed in live-poultry markets in China, where each of the viruses was found in species of birds other than its primary host ${ }^{163}$. In the 1980 s, a fatal outbreak of feline infectious peritonitis in cheetahs (Acinonyx jubatus) was caused by a feline coronavirus that circulates in domestic cats ${ }^{164}$. Within feline coronaviruses, type II feline coronavirus emerged from recombination between type I feline coronavirus and canine coronavirus $^{82,165}$, highlighting the potential role of co-infection in new hosts in the emergence of new coronaviruses. 
others have frequent contact. For example, humans in Oceania, Asia, Africa, South America and Pacific islands have long hunted fruit bats for food ${ }^{127,128}$. Humans in Thailand, the Philippines, Indonesia, Mexico and the United States harvest guano from bat caves for agricultural fertilizer ${ }^{129}$. Those long-term bat-human interactions contrast with the recent increasing emergence of highly virulent infections in humans linked to bats. Land-use change, animal farming and domestication, and human expansion into wildlands, among other factors, have been linked to the emergence of infectious diseases in general, and most likely play a role in spillover of bat-borne viruses ${ }^{3}$. Changes in the quality of bats' habitat may also affect their overall health and viral circulation owing to factors such as stress ${ }^{130}$. Low food availability, mediated by climate change and deforestation, appears to be a driver of shedding of other viruses in bats, including the zoonotic Hendra virus and Nipah virus ${ }^{131,132}$. Coronavirus shedding in horseshoe bats was higher in human-dominated landscapes than in natural landscapes ${ }^{16}$. In addition, the legal and illegal wildlife trade results in viruses being transported over longer distances within hosts maintained in stressful and unsanitary conditions, likely increasing shedding and transmission, as demonstrated for coronaviruses in rodents $^{5}$ and MERS-CoV in dromedary camels ${ }^{133}$.

Direct bat-to-human spillover. There are currently no well documented cases of direct bat-to-human spillover infections by coronaviruses, but this is likely due to inadequate surveillance rather than to a true absence of spillovers. Infections occurring in rural areas or in low-resource countries, where human-bat contacts might be common but access to health care is limited, likely go undetected. Furthermore, infection by some bat coronaviruses might be asymptomatic in humans or might be mistaken for other common diseases. Even for highly virulent pathogens for which surveillance programmes exist, such as Ebola virus or Nipah virus, reported spillover events appear to be the tip of the iceberg ${ }^{134,135}$ and are recognized only after substantial human-to-human transmission. In the case of Ebola virus, it takes on average 44 days of undetected transmission before an outbreak is recognized ${ }^{136}$.

Bat coronaviruses face numerous barriers that likely reduce infection and spread among humans. Those may occur at the levels of exposure (lack of bat virus-human contact), infection (coronavirus is not compatible with humans) or transmission (virus cannot be efficiently transmitted among humans). Perhaps, very few human exposures lead to infection, and even fewer to onward transmission. Studies in Asia have found serological evidence of human exposure to SARS-CoV or related viruses in healthy adults in Hong Kong and army recruits in mainland China sampled before the 2002 SARS pandemic ${ }^{137,138}$. More recent studies of villagers in the southern Chinese province of Yunnan found low seroprevalence of antibodies to SARSr-CoVs ${ }^{13,14}$. These studies suggest that bat-associated coronaviruses are potentially breaching the exposure and infection barriers, although the low seroprevalence (less than 3\%) indicates that such cases are rare, and these viruses are not efficiently spreading among humans. It is unknown whether the antibodies detected arise entirely from primary spillover or from a combination of primary cases with limited human-to-human transmission ${ }^{139,140}$. Syndromic surveillance at health-care facilities, combined with improved unbiased molecular diagnostic tools that could target unknown pathogens, and periodic serological surveys of human populations are important tools to provide better understanding of when, where and how coronavirus spillovers occur. Technologies such as phage immunoprecipitation sequencing or VirScan that use coronavirus sequences recovered from multiple species (including bats) would enable multiantigen testing that can reveal undetected past spillovers and other epidemics $^{141}$.

Spillover through bridging hosts. Besides bats, other animals may provide ecological, amplifying or evolutionary opportunities for coronavirus transmission from bats to humans ${ }^{9,78}$. Once infected from bats, such bridging hosts may promote virus spread to humans through increased exposure or high viral loads. This will lead to a higher probability of human exposure to infectious doses of the viruses, as seen for Hendra virus, where the initial spillover and infection of horses leads to exposure and infection in humans $s^{142}$, or for Nipah virus, through infection of swine ${ }^{143}$. In addition, bridging hosts may also enable viral evolution that results in new or enhanced zoonotic capacity ${ }^{78}$. Farmed Himalayan palm civets are thought to have served as bridge hosts in the spillover of SARS-CoV from bats to humans, and selection for enhanced viral replication in civets may have favoured viral mutations that increased zoonotic capacity $^{78,124,125}$. Endemic circulation of MERS-CoV in dromedary camels suggests that transmission of ancestral merbecoviruses from bats to camelids occurred decades or much longer ago, and likely resulted in evolution of zoonotic capacity ${ }^{13,144}$. Thus, MERS-CoV is considered a camelid virus with ancestral origins in bats ${ }^{145-147}$.

The ecological and evolutionary conditions that facilitated the spillover of SARS-CoV-2 remain unknown for now; however, circulation of closely related sarbecoviruses in horseshoe bats in Asia supports an ancestral origin in bats ${ }^{148}$. Whether the first SARS-CoV-2 transmission event happened directly from bats to humans or through a bridging host - possibly involving host-specific evolution that increased infectivity for humans - is unclear. However, coronaviruses closely related to SARS-CoV-2 with the capacity to infect humans cells have circulated widely in bats, supporting the possibility of direct bat-to-human transmission ${ }^{106}$.

In addition to the infection of humans from other reservoirs, humans can also act as bridging hosts for reverse zoonoses. Humans have infected domestic cats, dogs, large felids (for example, tigers (Panthera tigris)) and farmed American minks (Neovison vison) with SARS-CoV-2, which could potentially act as reservoirs for new variants ${ }^{149}$. In the specific case of farmed minks, SARS-CoV-2 can spread at epidemic levels, facilitating viral adaptation to the new host ${ }^{149}$. Thus, spillback to other wildlife species might lead to establishment in secondary reservoirs. ACE2 sequences of cricetid rodents suggest many are putatively susceptible to SARS-CoV-2. 
$R$

Reproductive number, the number of new infections generated by an average infected host in the population.

Metapopulation Spatial arrangement of populations of a species that are connected by migration processes.

Luminex

Technology that enables measurement of multiple proteins in a single well (sample).
Old World Syrian hamsters (Mesocricetus auratus), Chinese hamsters (Cricetulus griseus) and New World North American deer mice (Peromyscus maniculatus) are cricetid rodents that are susceptible to SARS-CoV-2 (REFS $\left.{ }^{150-153}\right)$. Although many wild and domestic animal species are susceptible and could even transmit the virus among themselves (for example, see REFS ${ }^{149,151,154-156}$ ), it is unclear for these species how transmission dynamics, population size, structure and connectivity, and eventual immunity would influence the establishment of continuous or temporary reservoirs. This evidence of reverse zoonosis or spillback calls for further research to elucidate the potential for other wild animal species becoming new viral reservoirs.

\section{Knowledge gaps and research agenda}

Fundamental knowledge gaps remain about the different conditions that result in coronaviruses passing from bats into humans. Dynamic integration among field studies, modelling, laboratory experiments and human epidemiology is required to understand the processes and to prevent new coronavirus spillovers and pandemics ${ }^{157}$.

The extensive study of coronavirus diversity in wild bats has yet to translate into a more profound understanding of their zoonotic capacity. For instance, it is unknown whether coronaviruses circulating in bat populations can be transmitted directly to humans and whether they can be transmitted among humans with $R>1$ without passage through bridging host species. Combining the probabilistic ecological drivers of spillover with an understanding of the molecular basis of host range and tropism will lead to a more comprehensive understanding of the zoonotic capacity of coronaviruses. To accomplish this, a high-throughput characterization of the zoonotic potential of bat coronaviruses using a tiered system of in silico, in vitro and in vivo methods is needed to understand the potential risk to humans.

Despite the rapidly growing number of genomic sequences of bat coronaviruses, our knowledge of the ecology and evolution of these viruses is still low. Understanding how, when and where viral shedding happens will directly inform how we assess the risk of spillover over time and space, as viral shedding and thus pathogen pressure is the first step in spillover. It remains unclear whether the spatiotemporal patterns of coronavirus prevalence and shedding seen in some bat populations are generalizable. To fill this gap, we need longitudinal studies at multiple scales, from the individual level to the population and metapopulation levels. These studies could be coupled with phylodynamic analyses of viruses to show how the natural evolution of bat coronavirus variants may result in emergence of cross-species and zoonotic capacity.
Our ability to understand mechanisms leading to successful spillover is limited by the apparent rarity of spillover events as well as by the limited ecological data available. Assessment of spillover risk requires an increased capacity to detect these events, especially those that are missed by public health surveillance. Serosurveys in humans and potential bridge hosts at risk of exposure to bat coronaviruses should be prioritized, and multiplex serological technologies, such as Luminex or VirScan, could facilitate wide screening, even when an agent has not been fully characterized ${ }^{141}$. Human-focused surveillance, coupled with spatiotemporal information on bat-virus interactions, viral discovery and functional characterization are needed to estimate the magnitude and frequency of spillover events that might have gone undetected in the past. It is urgent to implement this field research agenda, targeting high-risk interfaces in areas of rapid environmental change.

Finally, as we fill the gaps and integrate knowledge across scales and disciplines, we should also develop proactive strategies for spillover prevention, in addition to reactive outbreak mitigation. The exponential nature of epidemic growth makes stopping a new pathogen with efficient person-to-person transmission a difficult task, as demonstrated by SARS-CoV-2. As we understand the conditions that facilitate spillover, interventions to prevent those conditions will become clearer, and proactive actions may be taken to prevent the next coronavirus pandemic.

\section{Conclusions}

Coronaviruses that circulate in bat populations have spilled over into human populations several times, and most likely will continue to be a public health threat. The diversity and broad geographical distribution of bats, the ubiquitous shedding of coronaviruses from bat populations and the molecular interactions of coronaviruses facilitate their zoonotic capacity. However, these pathogens cannot cause outbreaks in humans unless the conditions for spillover and onward transmission are met. The risk of spillover depends on the level of human exposure, which is increasingly influenced by habitat deterioration and encroachment into wild areas. Integration of ecological, evolutionary and epidemiological data from bat-virus systems, coupled with human epidemiological and health surveillance in high-risk areas, is urgently needed to improve risk assessment and predictive capacity. This integration of scientific fields will provide the basis for new approaches to mitigate coronavirus outbreaks and prevent spillover to humans.

Published online 19 November 2021
1. Letko, M., Seifert, S. N., Olival, K. J., Plowright, R. K. \& Munster, V. J. Bat-borne virus diversity, spillover and emergence. Nat. Rev. Microbiol. 18, 461-471 (2020). This is a review of the overall diversity of bat-borne coronaviruses and research agenda for enhanced characterization of their zoonotic and pandemic potential.

2. Dobson, B. A. P. et al. Ecology and economics for pandemic prevention. Science 369, 379-381 (2020)

3. Plowright, R. K. et al. Land use-induced spillover: a call to action to safeguard environmental, animal, and human health. Lancet Planet. Heal. 5 , e237-e245 (2021).

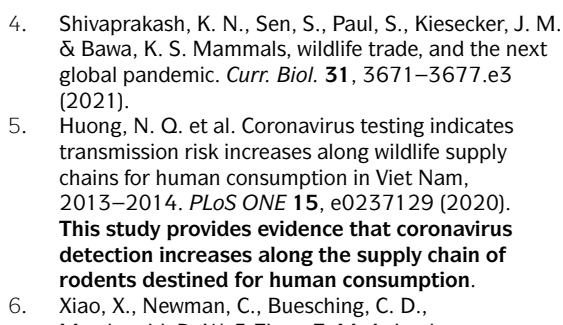

4. Shivaprakash, K. N., Sen, S., Paul, S., Kiesecker, J. M. $\&$ Bawa, K. S. Mammals, wildlife trade, and the next global pandemic. Curr. Biol. 31, 3671-3677.e3 (2021).

5. Huong, N. Q. et al. Coronavirus testing indicates transmission risk increases along wildlife supply chains for human consumption in Viet Nam, 2013-2014. PLOS ONE 15, e0237129 (2020). This study provides evidence that coronavirus detection increases along the supply chain of rodents destined for human consumption.

6. Xiao, X., Newman, C., Buesching, C. D., Macdonald, D. W. \& Zhou, Z.-M. Animal sales from Wuhan wet markets immediately prior to the COVID-19 pandemic. Sci. Rep. 11, 11898 (2021).

7. Chen, L., Liu, B., Yang, J. \& Jin, Q. DBatVir: the database of bat-associated viruses. Database 2014 , 1-7 (2014).

8. Tao, Y. et al. Surveillance of bat coronaviruses in Kenya identifies relatives of human coronaviruses NL63 and 229E and their recombination history. J. Virol. 91, 1-16 (2017).

9. Cui, J., Li, F. \& Shi, Z. L. Origin and evolution of pathogenic coronaviruses. Nat. Rev. Microbiol. 17, 181-192 (2019). 
10. Zhou, P. et al. A pneumonia outbreak associated with a new coronavirus of probable bat origin. Nature $\mathbf{5 7 9}$ 270-273 (2020)

This is one of the first studies to discove viruses related to SARS-CoV-2 in wild Rhinolophus spp. bats in China.

11. Forni, D., Cagliani, R., Clerici, M. \& Sironi, M Molecular evolution of human coronavirus genomes. Trends Microbiol. 25, 35-48 (2017).

12. Zhou, P. et al. Fatal swine acute diarrhoea syndrome caused by an HKU2-related coronavirus of bat origin Nature 556, 255-258 (2018).

13. Wang, N. et al. Serological evidence of bat SARS-related coronavirus infection in humans, China. Virol. Sin. 33, 104-107 (2018).

This study provides evidence of potentially undetected spillovers of bat-associated coronaviruses in rural human populations in China

14. Li, H. et al. Human-animal interactions and bat coronavirus spillover potential among rural residents in southern China. Biosaf. Heal. 1, 84-90 (2019).

15. Woo, P. C. Y. et al. Discovery of seven novel mammalian and avian coronaviruses in the genus Deltacoronavirus supports bat coronaviruses as the gene source of Alphacoronavirus and Betacoronavirus and avian coronaviruses as the gene source of Gammacoronavirus and Deltacoronavirus. J. Virol. 86 3995-4008 (2012).

16. Anthony, S. J. et al. Global patterns in coronavirus diversity. Virus Evol. 3, 1-15 (2017).

This is a review of ecological patterns of associations between bats and coronaviruses with information up to 2014

17. Li, W. et al. Bats are natural reservoirs of SARS-like coronaviruses. Science 310, 676-679 (2005).

18. Lau, S. K. P. et al. Severe acute respiratory syndrome coronavirus-like virus in Chinese horseshoe bats. Proc. Natl Acad. Sci. USA 102, 14040-14045 (2005).

19. Anthony, S. et al. Coronaviruses in bats from Mexico. J. Gen. Virol. 94, 1028-1038 (2013).

20. Latinne, A. et al. Origin and cross-species transmission of bat coronaviruses in China. Nat. Commun. 11 4235 (2020).

Using 5 years of surveillance data on coronaviruses in bats in China, the authors show that host switching is common in bat coronaviruses, particularly in Rhinolophus spp.

21. Ithete, N. L. et al. Close relative of human Middle East respiratory syndrome coronavirus in bat, South Africa. Emerg. Infect. Dis. 19, 1697-1699 (2013).

22. Råberg, L., Graham, A. L. \& Read, A. F. Decomposing health: tolerance and resistance to parasites in animals. Philos. Trans. R. Soc. Lond. B. Biol. Sci. 364, 37-49 (2009)

23. Schlottau, K. et al. SARS-CoV-2 in fruit bats, ferrets, pigs, and chickens: an experimental transmission study. Lancet Microbe 1, e218-e225 (2020).

24. Munster, V. J. et al. Replication and shedding of MERS-CoV in Jamaican fruit bats (Artibeus jamaicensis). Sci. Rep. 6, 1-10 (2016).

25. van Doremalen, $\mathrm{N}$. et al. SARS-like coronavirus WIV 1-CoV does not replicate in Egyptian fruit bats (Rousettus aegyptiacus). Viruses 10, 727 (2018).

26. Plowright, R. K. et al. Transmission or within-host dynamics driving pulses of zoonotic viruses in reservoir-host populations. PLoS Negl. Trop. Dis. 10, 1-21 (2016)

27. Jeong, J. et al. Persistent infections support maintenance of a coronavirus in a population of Australian bats (Myotis macropus). Epidemiol. Infect. 145, 2053-2061 (2017)

28. Watanabe, S. et al. Bat coronaviruses and experimental infection of bats, the Philippines. Emerg. Infect. Dis. 16, 1217-1223 (2010).

29. Subudhi, S. et al. A persistently infecting coronavirus in hibernating Myotis lucifugus, the North American little brown bat. J. Gen. Virol. 98, 2297-2309 (2017).

30. Widagdo, W. et al. Tissue distribution of the MERS-coronavirus receptor in bats. Sci. Rep. 7, 1-8 (2017).

31. Banerjee, A. et al. Selection of viral variants during persistent infection of insectivorous bat cells with Middle East respiratory syndrome coronavirus. Sci. Rep. 10, 7257 (2020)

32. Wang, M.-N. N. et al. Longitudinal surveillance of SARS-like coronaviruses in bats by quantitative real-time PCR. Virol. Sin. 31, 78-80 (2016).

33. Ge, X. Y. et al. Isolation and characterization of a bat SARS-like coronavirus that uses the ACE2 receptor. Nature 503, 535-538 (2013).
34. Hu, B. et al. Discovery of a rich gene pool of bat SARS-related coronaviruses provides new insights into the origin of SARS coronavirus. PLoS Pathog. 13 1-27 (2017)

35. Smith, C. Australian bat coronaviruses (The University of Queensland, 2015)

36. Baldwin, H. J. Epidemiology and ecology of virus and host: bats and coronaviruses in Ghana, West Africa (Macquarie University \& Ulm University, 2015).

37. Joffrin, L. et al. Bat coronavirus phylogeography in the Western Indian Ocean. Sci. Rep. 10, 1-11 (2020).

38. Plowright, R. K. et al. Reproduction and nutritional stress are risk factors for Hendra virus infection in little red flying foxes (Pteropus scapulatus). Proc. $R$ Soc. B Biol. Sci. 275, 861-869 (2008).

39. Peel, A. J. et al. Synchronous shedding of multiple bat paramyxoviruses coincides with peak periods of Hendra virus spillover. Emerg. Microbes Infect. 8 1314-1323 (2019)

This study provides evidence of co-circulation of multiple viruses in single and multispecies roosts of flying foxes, with higher diversity of viruses in mixed-species roosts.

40. Wacharapluesadee, S. et al. Longitudinal study of age-specific pattern of coronavirus infection in Lyle's flying fox (Pteropus lylei) in Thailand. Virol. J. 15, $1-10$ (2018)

41. Lau, S. K. P. et al. Ecoepidemiology and complete genome comparison of different strains of severe acute respiratory syndrome-related Rhinolophus bat coronavirus in China reveal bats as a reservoir for acute, self-limiting infection that allows recombination events. J. Virol. 84, 2808-2819 (2010).

42. Willoughby, A., Phelps, K. \& Olival, K. A comparative analysis of viral richness and viral sharing in cave-roosting bats. Diversity 9, 35 (2017).

43. Lloyd-Smith, J. O., Schreiber, S. J., Kopp, P. E. $\&$ Getz, W. M. Superspreading and the effect of individual variation on disease emergence. Nature 438, 355-359 (2005).

44. Lee, K. A. Linking immune defenses and life history at the levels of the individual and the species. Integr. Comp. Biol. 46, 1000-1015 (2006).

45. Robinson, D. P. \& Klein, S. L. Pregnancy and pregnancy-associated hormones alter immune responses and disease pathogenesis. Horm. Behav. 62, 263-271 (2012).

46. Pauly, M. et al. Novel alphacoronaviruses and paramyxoviruses cocirculate with type 1 and severe acute respiratory system (SARS)-related betacoronaviruses in synanthropic bats of Luxembourg. Appl. Environ. Microbiol. https://doi.org 10.1128/AEM.01326-17 (2017)

47. Drexler, J. F. et al. Amplification of emerging viruses in a bat colony. Emerg. Infect. Dis. 17, 449-456 (2011)

48. Annan, A. et al. Human betacoronavirus 2c EMC/2012-related viruses in bats, Ghana and Europe. Emerg. Infect. Dis. 19, 456-459 (2013).

49. Montecino-Latorre, D. et al. Reproduction of East-African bats may guide risk mitigation for coronavirus spillover. One Heal. Outlook 2, 2 (2020).

50. Plowright, R. K., Becker, D. J., McCallum, H. \& Manlove, K. R. Sampling to elucidate the dynamics of infections in reservoir hosts. Philos. Trans. R. Soc. B Biol. Sci. https://doi.org/10.1098/rstb.2018.0336 (2019).

51. Vanalli, C et al. Within-host mechanisms of immune regulation explain the contrasting dynamics of two helminth species in both single and dual infections. PLoS Comput. Biol. 16, 1-19 (2020).

52. Ge, X. Y. et al. Coexistence of multiple coronaviruses in several bat colonies in an abandoned mineshaft. Virol. Sin. 31, 31-40 (2016).

53. Chu, D. K. W., Peiris, J. S. M., Chen, H., Guan, Y. \& Poon, L. L. M. Genomic characterizations of bat coronaviruses (1 A, 1B and HKU8) and evidence for co-infections in Miniopterus bats. J. Gen. Virol. 89 1282-1287 (2008).

54. Drexler, J. F. et al. Genomic characterization of severe acute respiratory syndrome-related coronavirus in European bats and classification of coronaviruses based on partial RNA-dependent RNA polymerase gene sequences. J. Virol. 84, 11336-11349 (2010).

55. Tong, S. et al. Detection of novel SARS-like and other coronaviruses in bats from Kenya. Emerg. Infect. Dis. 15, 482-485 (2009)

56. Wacharapluesadee, S. et al. Diversity of coronavirus in bats from eastern Thailand emerging viruses. Virol. J. 12, 1-7 (2015).

57. Valitutto, M. T. et al. Detection of novel coronaviruses in bats in Myanmar. PLOS ONE 15, e0230802 (2020).
58. Anthony, S. J. et al. A strategy to estimate unknown viral diversity in mammals. mBio 4, 289 (2013).

59. Prada, D., Boyd V., Baker M. L., O'Dea, M \& Jackson, B. Viral diversity of microbats within the south west botanical province of Western Australia. Viruses 11, 1-21 (2019).

60. Seltmann, A. et al. Seasonal fluctuations of astrovirus, but not coronavirus shedding in bats inhabiting human-modified tropical forests. Ecohealth 14 272-284 (2017).

61. Chu, D. K. W., Poon, L. L. M., Guan, Y. \& Peiris, J. S M. Novel astroviruses in insectivorous Bats. J. Virol. 82, 9107-9114 (2008)

62. Kemenesi, G. et al. Molecular survey of RNA viruses in Hungarian bats: discovering novel astroviruses, coronaviruses, and caliciviruses. Vector Borne Zoonotic Dis. 14, 846-855 (2014).

63. Rizzo, F. et al. Coronavirus and paramyxovirus in bats from northwest Italy. BMC Vet. Res. 13, 1-11 (2017)

64. Paskey, A. C. et al. The temporal RNA virome patterns of a lesser dawn bat (Eonycteris spelaea) colony revealed by deep sequencing. Virus Evol. 6, 1-14 (2020).

65. Davy, C. M. et al. White-nose syndrome is associated with increased replication of a naturally persisting coronaviruses in bats. Sci. Rep. 8, 15508 (2018).

66. Woo, P. C. Y., Lau, S. K. P., Huang, Y. \& Yuen, K.-Y. Y. Coronavirus diversity, phylogeny and interspecies jumping. Exp. Biol. Med. 234, 1117-1127 (2009).

67. Fehr, A. R. \& Perlman, S. in Coronaviruses. Methods in Molecular Biology Vol 1282 (eds Maier, $\mathrm{H}$., Bickerton, E. \& Britton, P.) 1-23 (Humana Press, 2015).

68. Duffy, S., Shackelton, L. A. \& Holmes, E. C. Rates of evolutionary change in viruses: patterns and determinants. Nat. Rev. Genet. 9, 267-276 (2008).

69. Jenkins, G. M., Rambaut, A., Pybus, O. G. \& Holmes, E. C. Rates of molecular evolution in RNA viruses: a quantitative phylogenetic analysis. J. Mol. Evol. 54, 156-165 (2002).

70. Eckerle, L. D. et al. Infidelity of SARS-CoV Nsp14exonuclease mutant virus replication is revealed by complete genome sequencing. PLoS Pathog. 6, 1-15 (2010).

71. Ogando, N. S. et al. The curious case of the nidovirus exoribonuclease: its role in RNA synthesis and replication fidelity. Front. Microbiol. 10, 1-17 (2019).

72. Nga, P. T. et al. Discovery of the first insect nidovirus, a missing evolutionary link in the emergence of the largest RNA virus genomes. PLoS Pathog. 7 , e1002215 (2011).

73. Smith, E., Blanc, H., Vignuzzi, M. \& Denison, M. R. Coronaviruses lacking exoribonuclease activity are susceptible to lethal mutagenesis: evidence for proofreading and potential therapeutics. PLOS Pathog. 9, e1003565 (2013)

74. Martin, L. B et al. Extreme competence: keystone hosts of infections. Trends Ecol. Evol. 34, 303-314 (2019).

75. Graham, R. L. \& Baric, R. S. Recombination, reservoirs, and the modular spike: mechanisms of coronavirus cross-species transmission. J. Virol. 84 3134-3146 (2010).

76. Letko, M. et al. Adaptive evolution of MERS-CoV to species variation in DPP4. Cell Rep. 24, 1730-1737 (2018)

77. Ermonval, M., Baychelier, F. \& Tordo, N. What do we know about how hantaviruses interact with their different hosts? Viruses 8, 223 (2016).

78. Su, S. et al. Epidemiology, genetic recombination, and pathogenesis of coronaviruses. Trends Microbiol. 24 490-502 (2016).

79. Lai, M. M. et al. Recombination between nonsegmented RNA genomes of murine coronaviruses. J. Virol. 56, 449-456 (1985)

80. Tian, P.-F. et al. Evidence of recombinant strains of porcine epidemic diarrhea virus, United States, 2013. Emerg. Infect. Dis. 20, 1731-1734 (2014).

81. Terada, Y. et al. Emergence of pathogenic coronaviruses in cats by homologous recombination between feline and canine coronaviruses. PLOS ONE 9, e106534 (2014).

82. Decaro, N et al. Recombinant canine coronaviruses related to transmissible gastroenteritis virus of swine are circulating in dogs. J. Virol. 83, 1532-1537 (2009).

83. Zhang, Y. et al. Genotype shift in human coronavirus OC43 and emergence of a novel genotype by natural recombination. J. Infect. 70, 641-650 (2015).

84. Pyrc, K., Berkhout, B. \& van der hoek, L. in Recent Research in Development of Infection \& Immunity 3rd edn 25-48 (Transworld Research Network, 2005). 
85. Woo, P. C. Y. et al. Phylogenetic and recombination analysis of coronavirus HKU1, a novel coronavirus from patients with pneumonia. Arch. Virol. 150, 2299-2311 (2005)

86. Zhang, X. W., Yap, Y. L. \& Danchin, A. Testing the hypothesis of a recombinant origin of the SARS-associated coronavirus. Arch. Virol. 150, 1-20 (2005).

87. Stanhope, M. J., Brown, J. R. \& Amrine-Madsen, H. Evidence from the evolutionary analysis of nucleotide sequences for a recombinant history of SARS-CoV. Infect. Genet. Evol. 4, 15-19 (2004).

88. Wang, Y. et al. Origin and possible genetic recombination of the middle east respiratory syndrome coronavirus from the first imported case in China: phylogenetics and coalescence analysis. MBio 6, 1-6 (2015).

89. Huang, C. et al. A bat-derived putative cross-family recombinant coronavirus with a reovirus gene. PLoS Pathog. 12, 1-25 (2016).

This study provides evidence of cross-family recombination between coronaviruses and reoviruses.

90. Drexler, J. F., Corman, V. M. \& Drosten, C. Ecology, evolution and classification of bat coronaviruses in the aftermath of SARS. Antivir. Res. 101, 45-56 (2014).

91. Cui, J. et al. Evolutionary relationships between bat coronaviruses and their hosts. Emerg. Infect. Dis. 13, 1526-1532 (2007)

92. Davies, N. et al. Estimated transmissibility and impact of SARS-CoV-2 lineage B.1.1.7 in England. Sci 372, eabg3055 (2021).

93. Reguera, J., Mudgal, G., Santiago, C. \& Casasnovas, J. M. A structural view of coronavirus-receptor interactions. Virus Res. 194 3-15 (2014).

94. Lim, Y., Ng, Y., Tam, J. \& Liu, D. Human coronaviruses: a review of virus-host interactions. Diseases 4, 26 (2016).

95. Masters, P. S. \& Perlman, S. Coronaviridae. Fields Virol. 1, 825-858 (2013).

96. Letko, M., Marzi, A. \& Munster, V. Functional assessment of cell entry and receptor usage for SARS-CoV-2 and other lineage $B$ betacoronaviruses. Nat. Microbiol. 5, 562-569 (2020)

This study uses a functional viromics platform to rapidly characterize the zoonotic potential of new coronaviruses on the basis of genome sequences.

97. van Doremalen, N. et al. Host species restriction of middle east respiratory syndrome coronavirus through its receptor, dipeptidyl peptidase 4. J. Virol. 88, 9220-9232 (2014).

98. Conceicao, C. et al. The SARS-CoV-2 spike protein has a broad tropism for mammalian ACE2 proteins. PLoS Biol. 18, e3001016 (2020).

99. Li, W. et al. Receptor and viral determinants of SARS-coronavirus adaptation to human ACE2. EMBO J. 24, 1634-1643 (2005)

100. Damas, J. et al. Broad host range of SARS-CoV-2 predicted by comparative and structural analysis of ACE2 in vertebrates. Proc. Natl Acad. Sci. USA 117 22311-22322 (2020).

101. Shi, J. et al. Susceptibility of ferrets, cats, dogs, and other domesticated animals to SARS-coronavirus 2 Science 1020, 1016-1020 (2020).

102. Oude Munnink, B. B. et al. Transmission of SARS-CoV-2 on mink farms between humans and mink and back to humans. Science 371, 172-177 (2021). The study provides evidence of spillback of SARS-CoV-2 into mink populations, rapid and widespread transmission, and seeding of mink-associated genetic variants back into humans.

103. Hoffmann, M. et al. Differential sensitivity of bat cells to infection by enveloped RNA viruses: coronaviruses, paramyxoviruses, filoviruses, and influenza viruses. PLOS ONE 8, e72942 (2013)

104. Li, W. et al. Animal origins of the severe acute respiratory syndrome coronavirus: insight from ACE2-S-protein interactions. J. Virol. 80, 4211-4219 (2006).

105. Hou, Y. et al. Angiotensin-converting enzyme 2 (ACE2) proteins of different bat species confer variable susceptibility to SARS-CoV entry. Arch. Virol. 155 1563-1569 (2010)

106. Boni, M. F. et al. Evolutionary origins of the SARS-CoV-2 sarbecovirus lineage responsible for the COVID-19 pandemic. Nat. Microbiol. 5, 1408-1417 (2020). This study provids phylogenetic evidence that suggests that the ancestral lineages from which SARS-CoV-2 may have originated have circulated undetected in bats for decades.
107. Wells, H. L. et al. The evolutionary history of ACE2 usage within the coronavirus subgenus Sarbecovirus. Virus Evol. 7, 1-22 (2021).

108. Urbanowicz, R. A. et al. Human adaptation of Ebola virus during the West African outbreak. Cell 167, 1079-1087.e5 (2016).

109. Gupta, A. et al. Extrapulmonary manifestations of COVID-19. Nat. Med. 26, 1017-1032 (2020).

110. Hamming, I. et al. Tissue distribution of ACE2 protein the functional receptor for SARS coronavirus. A first step in understanding SARS pathogenesis. J. Pathol. 203, 631-637 (2004)

111. Lam, T. T. Y. et al. Identifying SARS-CoV-2-related coronaviruses in Malayan pangolins. Nature $\mathbf{5 8 3}$ 282-285 (2020).

112. Martina, B. E. E. et al. SARS virus infection of cats and ferrets. Nature 425, 915 (2003).

113. Munster, V. J. et al. Respiratory disease in rhesus macaques inoculated with SARS-CoV-2. Nature 585 , 268-272 (2020)

114. Hou, Y. J. et al. SARS-CoV-2 reverse genetics reveals a variable infection gradient in the respiratory tract. Cell 182, 429-446.e 14 (2020).

115. Menachery, V. D. et al. Trypsin treatment unlocks barrier for zoonotic bat coronavirus infection. J. Virol. 94, 1-15 (2019)

116. Qian, Z., Dominguez, S. R. \& Holmes, K. V. Role of the spike glycoprotein of human Middle East respiratory syndrome coronavirus (MERS-CoV) in virus entry and syncytia formation. PLOS ONE 8, 1-12 (2013).

117. Belouzard, S., Chu, V. C. \& Whittaker, G. R. Activation of the SARS coronavirus spike protein via sequential proteolytic cleavage at two distinct sites. Proc. Natl Acad. Sci. USA 106, 5871-5876 (2009).

118. Barlan, A. et al. Receptor variation and susceptibility to middle east respiratory syndrome coronavirus infection. J. Virol. 88, 4953-4961 (2014).

119. Zheng, Y. et al. Lysosomal proteases are a determinant of coronavirus tropism. J. Virol. 92, 1-14 (2018)

120. Bertram, S. et al. Cleavage and activation of the severe acute respiratory syndrome coronavirus spike protein by human airway trypsin-like protease. J. Virol. 85, 13363-13372 (2011).

121. Matsuyama, S., Ujike, M., Morikawa, S., Tashiro, M. \& Taguchi, F. Protease-mediated enhancement of severe acute respiratory syndrome coronavirus infection. Proc. Natl Acad. Sci. USA 102, 12543-12547 (2005).

122. Yang, Y. et al. Receptor usage and cell entry of bat coronavirus HKU4 provide insight into bat-to-human transmission of MERS coronavirus. Proc. Natl Acad. Sci. USA 111, 12516-12521 (2014).

123. Wacharapluesadee, S. et al. Group C betacoronavirus in bat guano fertilizer, Thailand. Emerg. Infect. Dis. 19, 1349-1351 (2013)

124. Luk, H. K. H., Li, X., Fung, J., Lau, S. K. P. \& Woo, P. C. Y. Molecular epidemiology, evolution and phylogeny of SARS coronavirus. Infect. Genet. Evol. 71, 21-30 (2019).

125. Wu, K., Peng, G., Wilken, M., Geraghty, R. J. \& Li, F. Mechanisms of host receptor adaptation by severe acute respiratory syndrome coronavirus. J. Biol. Chem 287, 8904-8911 (2012)

126. Daszak, P., Olival, K. J. \& Li, H. A strategy to prevent future epidemics similar to the 2019-nCoV outbreak. Biosaf. Heal. 2, 6-8 (2020).

127. Tidemann, C. $\&$ Vardon, M. Pests, pestilence, pollen and pot roasts: the need for community based management of flying foxes in Australia. Aust. Biol. 10, 77-83 (1997)

128. Mickleburgh, S., Waylen, K. \& Racey, P. Bats as bushmeat: a global review. Oryx 43, 217-234 (2009).

129. Tuttle, M. D. \& Moreno, A. Cave-Dwelling Bats of Northern Mexico: Their Value and Conservation Needs (Bat Conservation International, 2005).

130. Rulli, M. C., D'Odorico, P., Galli, N. \& Hayman, D. T. S. Land-use change and the livestock revolution increase the risk of zoonotic coronavirus transmission from rhinolophid bats. Nat. Food https://doi.org/10.1038/ s43016-021-00285-x (2021).

131. Mckee, C. D., Islam, A., Luby, S. P., Salje, H. \& Hudson, P. J. The ecology of Nipah virus in Bangladesh: a nexus of land use change and opportunistic feeding behavior in bats. Viruses 13 , 169 (2020).

132. Kessler, M. K. et al. Changing resource landscapes and spillover of henipaviruses. Ann. N. Y. Acad. Sci. https://doi.org/10.1111/nyas. 13910 (2018).

133. Dighe, A., Jombart, T., Van Kerkhove, M. D. \& Ferguson, N. A systematic review of MERS-CoV seroprevalence and RNA prevalence in dromedary camels: implications for animal vaccination. Epidemics 29, 100350 (2019).

134. Hegde, S. T. et al. Using healthcare-seeking behaviour to estimate the number of Nipah outbreaks missed by hospital-based surveillance in Bangladesh. Int. J. Epidemiol. 48, 1219-1227 (2019).

135. Glennon, E. E., Jephcott, F. L., Restif, O. \& Wood, J. L. N. Estimating undetected Ebola spillovers. PLoS Negl. Trop. Dis. 13, 1-10 (2019).

136. Matson, M. J., Chertow, D. S. \& Munster, V. J. Delayed recognition of Ebola virus disease is associated with longer and larger outbreaks. Emerg. Microbes Infect. 9, 291-301 (2020).

137. Zheng, B. J. et al. SARS-related virus predating SARS outbreak, Hong Kong. Emerg. Infect. Dis. 10 176-178 (2004). This study provides serological evidence that populations in Hong Kong sampled in 2001 may have been exposed to SARS-CoV or related viruses in bats or other animals before the first SARS outbreaks.

138. Yu, S. et al. Retrospective serological investigation of severe acute respiratory syndrome coronavirus antibodies in recruits from mainland China. Clin. Diagn. Lab. Immunol. 12, 552-554 (2005).

139. Lloyd-Smith, J. O. et al. Epidemic dynamics at the human-animal interface. Science 326, 1362-1367 (2009).

140. Plowright, R. K. et al. Pathways to zoonotic spillover Nat. Rev. Microbiol. 15, 502-510 (2017).

This study formulates a conceptual model for the multiple layers of ecological and cellular barriers that affect the likelihood of pathogen spillover from animals.

141. Klompus, S. et al. Cross-reactive antibodies against human coronaviruses and the animal coronavirome suggest diagnostics for future zoonotic spillovers. Sci. Immunol. 6, eabe9950 (2021).

142. Field, H. E. Hendra virus ecology and transmission. Curr. Opin. Virol. 16, 120-125 (2016).

143. Chua, K. B. Nipah virus outbreak in Malaysia. J. Clin. Virol. 26, 265-275 (2003).

144. Azhar, E. I. et al. Evidence for camel-to-human transmission of MERS coronavirus. N. Engl. J. Med. 370, 2499-2505 (2014).

145. Memish, Z. A. et al. Respiratory tract samples, viral load, and genome fraction yield in patients with middle east respiratory syndrome. J. Infect. Dis. $\mathbf{2 1 0}$, 1590-1594 (2014).

146. Buchholz, U. et al. Contact investigation of a case of human novel coronavirus infection treated in a German hospital, October-November 2012 Eurosurveillance 18, 1-7 (2013).

147. Chu, D. K. W. et al. MERS coronaviruses in dromedary camels, Egypt. Emerg. Infect. Dis. 20, 1049-1053 (2014).

148. Zhou, $\mathrm{H}$. et al. Identification of novel bat coronaviruses sheds light on the evolutionary origins of SARS-CoV-2 and related viruses. Cell 184, 4380-4391.e14 (2021).

This study reports the discovery of additional coronaviruses related to SARS-CoV-2 in Rhinolophus spp. and use of ecological modelling to highlight areas of southern China and South-East Asia as hotspots of Rhinolophus species diversity.

149. Larsen, H. D. et al. Preliminary report of an outbreak of SARS-CoV-2 in mink and mink farmers associated with community spread, Denmark, June to November 2020. Eur. Surveill. 26, 2100009 (2021).

150. Bertzbach, L. D. et al. SARS-CoV-2 infection of Chinese hamsters (Cricetulus griseus) reproduces COVID-19 pneumonia in a well-established small animal model. Transbound. Emerg. Dis. 68, 1075-1079 (2021)

151. Fagre, A. et al. SARS-CoV-2 infection, neuropathogenesis and transmission among deer mice: Implications for spillback to New World rodents. PLoS Pathog. 17, e1009585 (2021).

152. Imai, M. et al. Syrian hamsters as a small animal model for SARS-CoV-2 infection and countermeasure development. Proc. Natl Acad. Sci. USA 117 16587-16595 (2020).

153. Sia, S. F. et al. Pathogenesis and transmission of SARS-CoV-2 in golden hamsters. Nature $\mathbf{5 8 3}$, 834-838 (2020).

154. Halfmann, P. J. et al. Transmission of SARS-CoV-2 in domestic cats. N. Engl. J. Med. 383, 592-594 (2020).

155. Griffin, B. D. et al. SARS-CoV-2 infection and transmission in the North American deer mouse. Nat. Commun. 12, 1-10 (2021). 
156. Palmer, M. V. et al. Susceptibility of white-tailed dee (Odocoileus virginianus) to SARS-CoV-2 J Virol. 95 e00083-21 (2021)

157. Plowright, R. K. \& Hudson, P. J. From protein to pandemic: the transdisciplinary approach needed to prevent spillover and the next pandemic. Viruses 13 $1298(2021)$.

158. Obameso, J. O. et al. The persistent prevalence and evolution of cross-family recombinant coronavirus GCCDC1 among a bat population: a two-year follow-up. Sci. China Life Sci. 60, 1357-1363 (2017).

This study provides evidence of coronavirus evolution in a longitudinally sampled population of bats.

159. Lazov, C. et al. Detection and characterization of distinct alphacoronaviruses in five different bat species in Denmark. Viruses 10, 486 (2018).

160. Hu, D. et al. Genomic characterization and infectivity of a novel SARS-like coronavirus in Chinese bats. Emerg. Microbes Infect. 7, 1-10 (2018).

161. Pepin, K. M. Lass, S., Pulliam, J. R. C. Read, A. F. \& Lloyd-Smith, J. O. Identifying genetic markers of adaptation for surveillance of viral host jumps. Nat. Rev. Microbiol. 8, 802-813 (2010).

162. Hemida, M. G. et al. Coronavirus infections in horses in Saudi Arabia and Oman. Transbound. Emerg. Dis. 64, 2093-2103 (2017)

163. Zhuang, Q. et al. Surveillance and taxonomic analysis of the coronavirus dominant in pigeons in China. Transbound Emerg. Dis. 67, 1981-1990 (2020).
164. O’Brien, S. J. et al. Genetic basis for species vulnerability in the cheetah. Science 227 1428-1434 (1985).

165. Herrewegh, A. A. P. M., Smeenk, I., Horzinek, M. C. Rottier, P. J. M. \& de Groot, R. J. Feline coronavirus type II strains $79-1683$ and $79-1146$ originate from a double recombination between feline coronavirus type I and canine coronavirus. J. Virol. 72, 4508-4514 (1998)

Acknowledgements

Work related to this Review was supported by the Defense Advanced Research Projects Agency (PREEMPT D18AC00031). M.R.-A., D.N.J., M.K.K., C.F., D.C., N.B. A.J.P., O.R., P.J.H. and R.K.P. were supported by the US National Science Foundation (DEB-1716698). R.K.P. was supported by the US Department of Agriculture National Institute of Food and Agriculture (Hatch project 1015891) J.O.L.-S. and A.G. were supported by the UCLA AIDS Institute and Charity Treks and by the US National Science Foundation (DEB-1557022). C.E.S was supported by the US National Institutes of Health (T32 GM008185-33). C.K.Y J R.P. and V.J.M. are supported by the Intramural Research Program of the US National Institute of Allergy and Infectious Diseases, US National Institutes of Health. A.J.P. was supported by an ARC DECRA fellowship (DE190100710). O.R. is supported by the ALBORADA Trust. E.J. is funded by a research fellowship from the Deutsche Forschungsgemeinschaft (438001934). C.E.B. was funded by a postdoctoral fellowship from the Miller Institute for Basic Research, a Branco Weiss Society in Science Fellowship and US National Institutes of Health grant R01AI1 29822-01. D.W.B., Y.Y.Y. and H.C.A. were supported by US National Institutes of Health grants R01AI 109022 and R21Al142377.

Author contributions

M.R.-A., C.M. and R.K.P. conceived the study. M.R.-A., C.M., R.K.P., A.G., C.R.P., E.S.G., J.O.L.-S., P.J.H. and V.J.M. contributed substantially to discussion of the content. M.R.A. C.M., C.F., E.J., L.D., D.N.J. and M.K.K. compiled the data and performed formal analysis. M.R.-A. and C.M. contributed equally. All authors wrote the article and reviewed and/or edited the manuscript before submission.

\section{Competing interests}

The authors declare no competing interests.

Peer review information

Nature Reviews Microbiology thanks Jie Cui and Vikram Misra for their contribution to the peer review of this work.

Publisher's note

Springer Nature remains neutral with regard to jurisdictional claims in published maps and institutional affiliations.

\section{Supplementary information}

The online version contains supplementary material available at https://doi.org/10.1038/s41579-021-00652-2.

\section{RELATED LINKS}

Bat Species of the World database: https://batnames.org/

(c) Springer Nature Limited 2021, corrected publication 2022 
Supplementary information

\section{Ecology, evolution and spillover of coronaviruses from bats}

In the format provided by the authors and unedited 
Supplementary Table 1. Wild bat hosts of coronaviruses reported in published studies. All coronaviruses were considered in our search, but we highlight links between bat species and key bat coronavirus subgenera associated with human infections (e.g., Sarbecovirus), domestic animal infections (e.g., Rhinacovirus), or are widespread and well characterized (e.g., Nobecovirus) based on sequencing information available in the associated studies.

\begin{tabular}{|c|c|c|c|}
\hline Bat species & Bat family & $\begin{array}{l}\text { Key coronavirus } \\
\text { subgenera }\end{array}$ & Reference \\
\hline Emballonura alecto & Emballonuridae & Nobecovirus & 5 \\
\hline Taphozous melanopogon & Emballonuridae & & 1,9 \\
\hline Taphozous perforatus & Emballonuridae & Merbecovirus & 10,11 \\
\hline Aselliscus stoliczkanus & Hipposideridae & $\begin{array}{l}\text { Rhinacovirus } \\
\text { Sarbecovirus }\end{array}$ & $12,145,163,173,174$ \\
\hline Hipposideros abae & Hipposideridae & Duvinacovirus & 13 \\
\hline Hipposideros armiger & Hipposideridae & $\begin{array}{l}\text { Hibecovirus } \\
\text { Merbecovirus } \\
\text { Nobecovirus } \\
\text { Rhinacovirus } \\
\text { Sarbecovirus } \\
\end{array}$ & $1,9,14-17,145,174$ \\
\hline Hipposideros bicolor & Hipposideridae & & 1 \\
\hline Hipposideros caffer & Hipposideridae & $\begin{array}{l}\text { Duvinacovirus } \\
\text { Hibecovirus } \\
\text { Sarbecovirus }\end{array}$ & $1-4,142,163,172$ \\
\hline Hipposideros cervinus & Hipposideridae & & 18,163 \\
\hline Hipposideros cf. caffer & Hipposideridae & $\begin{array}{l}\text { Duvinacovirus } \\
\text { Hibecovirus }\end{array}$ & 19 \\
\hline Hipposideros cf. ruber & Hipposideridae & $\begin{array}{l}\text { Duvinacovirus } \\
\text { Hibecovirus }\end{array}$ & $13,20-22$ \\
\hline Hipposideros cineraceus & Hipposideridae & Rhinacovirus & 23,152 \\
\hline Hipposideros curtus & Hipposideridae & Duvinacovirus & 163,172 \\
\hline Hipposideros diadema & Hipposideridae & & $1,5,163$ \\
\hline Hipposideros fuliginosus & Hipposideridae & Hibecovirus & 163,172 \\
\hline Hipposideros galeritus & Hipposideridae & Sarbecovirus & 1 \\
\hline Hipposideros gentilis & Hipposideridae & & 169 \\
\hline $\begin{array}{l}\text { Hipposideros } \\
\text { khaokhouayensis }\end{array}$ & Hipposideridae & & 169 \\
\hline Hipposideros larvatus & Hipposideridae & $\begin{array}{l}\text { Hibecovirus } \\
\text { Nobecovirus } \\
\text { Rhinacovirus } \\
\text { Sarbecovirus }\end{array}$ & $1,9,15,26,27,152,163,173,174$ \\
\hline Hipposideros lekaguli & Hipposideridae & Nobecovirus & $1,9,163$ \\
\hline Hipposideros pomona & Hipposideridae & $\begin{array}{l}\text { Hibecovirus } \\
\text { Rhinacovirus } \\
\text { Sarbecovirus }\end{array}$ & $28-30,145,152,163,173,174$ \\
\hline Hipposideros pratti & Hipposideridae & $\begin{array}{l}\text { Hibecovirus } \\
\text { Rhinacovirus } \\
\text { Sarbecovirus }\end{array}$ & $1,31,145$ \\
\hline Hipposideros ruber & Hipposideridae & $\begin{array}{l}\text { Duvinacovirus } \\
\text { Hibecovirus } \\
\text { Nobecovirus } \\
\text { Sarbecovirus }\end{array}$ & $1,4,141,142,156,163,172$ \\
\hline
\end{tabular}




\begin{tabular}{|c|c|c|c|}
\hline Bat species & Bat family & $\begin{array}{l}\text { Key coronavirus } \\
\text { subgenera }\end{array}$ & Reference \\
\hline $\begin{array}{l}\text { Macronycteris gigas } \\
\text { (formerly Hipposideros } \\
\text { gigas) }\end{array}$ & Hipposideridae & $\begin{array}{l}\text { Duvinacovirus } \\
\text { Hibecovirus }\end{array}$ & $1,22,142,163,172$ \\
\hline $\begin{array}{l}\text { Macronycteris vittatus } \\
\text { (formerly Hipposideros } \\
\text { commersoni) }\end{array}$ & Hipposideridae & $\begin{array}{l}\text { Duvinacovirus } \\
\text { Hibecovirus } \\
\text { Nobecovirus }\end{array}$ & $24,25,32$ \\
\hline Cardioderma cor & Megadermatidae & & 24,32 \\
\hline $\begin{array}{l}\text { Lyroderma lyra } \\
\text { (formerly Megaderma } \\
\text { (yra) }\end{array}$ & Megadermatidae & & $1,9,163,174$ \\
\hline Miniopterus africanus & Miniopteridae & & 24 \\
\hline Miniopterus australis & Miniopteridae & & 33 \\
\hline Miniopterus fuliginosus & Miniopteridae & & $1,14,30,31,34,35,140,162,171$ \\
\hline Miniopterus fuscus & Miniopteridae & & 30,145 \\
\hline Miniopterus inflatus & Miniopteridae & & $1,22,24,142$ \\
\hline Miniopterus magnater & Miniopteridae & & $1,9,36-39,163$ \\
\hline Miniopterus minor & Miniopteridae & & $2,24,32$ \\
\hline Miniopterus mossambicus & Miniopteridae & & 3 \\
\hline Miniopterus natalensis & Miniopteridae & & 7,24 \\
\hline Miniopterus pusillus & Miniopteridae & & $9,36-40,145,163,174$ \\
\hline Miniopterus schreibersii & Miniopteridae & $\begin{array}{l}\text { Merbecovirus } \\
\text { Rhinacovirus } \\
\text { Sarbecovirus }\end{array}$ & $8,9,17,30,33,37,41-47,140,145,163,171,174$ \\
\hline Chaerephon plicatus & Molossidae & $\begin{array}{l}\text { Merbecovirus } \\
\text { Sarbecovirus }\end{array}$ & $26,31,48,49,152,169,174$ \\
\hline Chaerephon pumilus & Molossidae & $\begin{array}{l}\text { Duvinacovirus } \\
\text { Nobecovirus }\end{array}$ & $1-4,6,24,142,163$ \\
\hline Cynomops abrasus & Molossidae & & 50 \\
\hline Cynomops planirostris & Molossidae & & 50 \\
\hline Eumops glaucinus & Molossidae & Merbecovirus & 51 \\
\hline Molossus currentium & Molossidae & & 52 \\
\hline Molossus molossus & Molossidae & & $53-55$ \\
\hline Molossus rufus & Molossidae & & $51,52,54,55$ \\
\hline Mops condylurus & Molossidae & $\begin{array}{l}\text { Hibecovirus } \\
\text { Nobecovirus }\end{array}$ & $1-3,6,142,163,172$ \\
\hline Mops midas & Molossidae & & $3,7,163$ \\
\hline $\begin{array}{l}\text { Mormopterus } \\
\text { francoismoutoui }\end{array}$ & Molossidae & & 3 \\
\hline Mormopterus jugularis & Molossidae & & 3 \\
\hline Nyctinomops laticaudatus & Molossidae & Merbecovirus & 1,56 \\
\hline Otomops martiensseni & Molossidae & & $24,32,163$ \\
\hline Tadarida brasiliensis & Molossidae & & $1,53,56,158$ \\
\hline Tadarida teniotis & Molossidae & Sarbecovirus & 8,57 \\
\hline Pteronotus davyi & Mormoopidae & & 54 \\
\hline Pteronotus parnellii & Mormoopidae & & $1,52,56$ \\
\hline Pteronotus personatus & Mormoopidae & & 1 \\
\hline Mystacina tuberculata & Mystacinidae & & 58 \\
\hline Nycteris cf. gambiensis & Nycteridae & Merbecovirus & 59 \\
\hline Nycteris macrotis & Nycteridae & Merbecovirus & 141 \\
\hline
\end{tabular}




\begin{tabular}{|c|c|c|c|}
\hline Bat species & Bat family & $\begin{array}{l}\text { Key coronavirus } \\
\text { subgenera }\end{array}$ & Reference \\
\hline Nycteris thebaica & Nycteridae & Merbecovirus & 3 \\
\hline Nycteris tragata & Nycteridae & & 163 \\
\hline Anoura caudifer & Phyllostomidae & & 1,163 \\
\hline Anoura geoffroyi & Phyllostomidae & & 52 \\
\hline Artibeus jamaicensis & Phyllostomidae & & $1,52,56,60$ \\
\hline Artibeus lituratus & Phyllostomidae & & $1,51,52,55,56$ \\
\hline Artibeus obscurus & Phyllostomidae & & 1,163 \\
\hline Artibeus planirostris & Phyllostomidae & & 1,163 \\
\hline Carollia brevicauda & Phyllostomidae & & 52 \\
\hline Carollia castanea & Phyllostomidae & & 60 \\
\hline Carollia perspicillata & Phyllostomidae & & $1,51,52,56,60,61$ \\
\hline Carollia sowelli & Phyllostomidae & & 1,56 \\
\hline $\begin{array}{l}\text { Dermanura phaeotis } \\
\text { (formerly Artibeus } \\
\text { phaeotis) }\end{array}$ & Phyllostomidae & & 1,56 \\
\hline Desmodus rotundus & Phyllostomidae & & $50,62,63,143,164$ \\
\hline Glossophaga soricina & Phyllostomidae & & $1,50,51,55,60,61$ \\
\hline Lichonycteris obscura & Phyllostomidae & & 163 \\
\hline Lonchorhina aurita & Phyllostomidae & & 1,56 \\
\hline Mesophylla macconnelli & Phyllostomidae & & 1,163 \\
\hline Phyllostomus discolor & Phyllostomidae & & 52,55 \\
\hline Sturnira erythromos & Phyllostomidae & & 1,163 \\
\hline Sturnira lilium & Phyllostomidae & & 1,51 \\
\hline Acerodon celebensis & Pteropodidae & Nobecovirus & 163 \\
\hline Cynopterus brachyotis & Pteropodidae & Nobecovirus & $1,5,9,27,64,65,163,170$ \\
\hline Cynopterus horsfieldii & Pteropodidae & Nobecovirus & 1,163 \\
\hline Cynopterus sphinx & Pteropodidae & Nobecovirus & $1,9,23,27,145,147,163,169$ \\
\hline Dobsonia moluccensis & Pteropodidae & Nobecovirus & 66 \\
\hline Dyacopterus spadiceus & Pteropodidae & Nobecovirus & 1 \\
\hline Eidolon dupreanum & Pteropodidae & Nobecovirus & 67 \\
\hline Eidolon helvum & Pteropodidae & Nobecovirus & $1,2,4,6,10,11,24,32,68,141,142,163,172$ \\
\hline Eonycteris spelaea & Pteropodidae & Nobecovirus & $1,27,64,69-71,144,145,163,169,174$ \\
\hline Epomophorus gambianus & Pteropodidae & Nobecovirus & $1,141,156,163,172$ \\
\hline Epomophorus labiatus & Pteropodidae & Nobecovirus & 4,32 \\
\hline Epomops buettikoferi & Pteropodidae & Nobecovirus & 163 \\
\hline Epomops franqueti & Pteropodidae & Nobecovirus & $1,142,163,172$ \\
\hline Macroglossus minimus & Pteropodidae & Nobecovirus & $5,72,170$ \\
\hline Megaerops ecaudatus & Pteropodidae & Nobecovirus & 163 \\
\hline Megaerops kusnotoi & Pteropodidae & Nobecovirus & 23 \\
\hline Megaerops niphanae & Pteropodidae & Nobecovirus & 1,27 \\
\hline $\begin{array}{l}\text { Megaloglossus } \\
\text { woermanni }\end{array}$ & Pteropodidae & Nobecovirus & $1,142,163,172$ \\
\hline Micropteropus pusillus & Pteropodidae & Nobecovirus & $1,20,142,163,172$ \\
\hline $\begin{array}{l}\text { Myonycteris angolensis } \\
\text { (formerly Lissonycteris } \\
\text { angolensis) }\end{array}$ & Pteropodidae & $\begin{array}{l}\text { Duvinacovirus } \\
\text { Hibecovirus } \\
\text { Nobecovirus }\end{array}$ & $1,4,6,141,163$ \\
\hline Myonycteris torquata & Pteropodidae & Nobecovirus & 163,172 \\
\hline Nanonycteris veldkampii & Pteropodidae & Nobecovirus & 141 \\
\hline Ptenochirus jagori & Pteropodidae & Nobecovirus & 5,64 \\
\hline
\end{tabular}




\begin{tabular}{|c|c|c|c|}
\hline Bat species & Bat family & $\begin{array}{l}\text { Key coronavirus } \\
\text { subgenera }\end{array}$ & Reference \\
\hline Pteropus alecto & Pteropodidae & Nobecovirus & $1,33,73$ \\
\hline Pteropus conspicillatus & Pteropodidae & Nobecovirus & 163 \\
\hline Pteropus lylei & Pteropodidae & Nobecovirus & 74,163 \\
\hline $\begin{array}{l}\text { Pteropus medius } \\
\text { (formerly Pteropus } \\
\text { giganteus) }\end{array}$ & Pteropodidae & Nobecovirus & $1,75-77,163$ \\
\hline Pteropus rufus & Pteropodidae & Nobecovirus & 67 \\
\hline Rousettus aegyptiacus & Pteropodidae & Nobecovirus & $1,2,4,6,24,32,78,141,163,172$ \\
\hline $\begin{array}{l}\text { Rousettus } \\
\text { amplexicaudatus }\end{array}$ & Pteropodidae & Nobecovirus & $1,5,27,64,170$ \\
\hline Rousettus leschenaultii & Pteropodidae & $\begin{array}{l}\text { Merbecovirus } \\
\text { Nobecovirus }\end{array}$ & $1,23,27-29,40,71,79-81,159,162,163,174$ \\
\hline $\begin{array}{l}\text { Rousettus } \\
\text { madagascariensis }\end{array}$ & Pteropodidae & Nobecovirus & 3 \\
\hline Rhinolophus acuminatus & Rhinolophidae & Sarbecovirus & 151,163 \\
\hline Rhinolophus affinis & Rhinolophidae & $\begin{array}{l}\text { Rhinacovirus } \\
\text { Sarbecovirus }\end{array}$ & $1,12,30,47,82,83,145,146,161,163,169,174$ \\
\hline Rhinolophus blasii & Rhinolophidae & $\begin{array}{l}\text { Rhinacovirus } \\
\text { Sarbecovirus }\end{array}$ & 45,163 \\
\hline Rhinolophus cf. clivosus & Rhinolophidae & $\begin{array}{l}\text { Duvinacovirus } \\
\text { Sarbecovirus }\end{array}$ & 6,139 \\
\hline Rhinolophus clivosus & Rhinolophidae & $\begin{array}{l}\text { Duvinacovirus } \\
\text { Hibecovirus } \\
\text { Rhinacovirus, } \\
\text { Sarbecovirus }\end{array}$ & $1,4,84$ \\
\hline Rhinolophus cornutus & Rhinolophidae & Sarbecovirus & 85,148 \\
\hline Rhinolophus creaghi & Rhinolophidae & Sarbecovirus & 1,163 \\
\hline Rhinolophus darlingi & Rhinolophidae & & 141 \\
\hline Rhinolophus euryale & Rhinolophidae & $\begin{array}{l}\text { Rhinacovirus } \\
\text { Sarbecovirus }\end{array}$ & $8,45,86,163$ \\
\hline $\begin{array}{l}\text { Rhinolophus } \\
\text { ferrumequinum }\end{array}$ & Rhinolophidae & $\begin{array}{l}\text { Merbecovirus } \\
\text { Nobecovirus } \\
\text { Rhinacovirus } \\
\text { Sarbecovirus }\end{array}$ & $\begin{array}{l}1,8,12,17,23,29,31,43-45,57,78,83,86,89- \\
93,140,145,159,160,163,171,174\end{array}$ \\
\hline Rhinolophus fumigatus & Rhinolophidae & & 2 \\
\hline Rhinolophus hildebrandtii & Rhinolophidae & Sarbecovirus & 32 \\
\hline Rhinolophus hipposideros & Rhinolophidae & Sarbecovirus & $86,94,95,160,165$ \\
\hline Rhinolophus landeri & Rhinolophidae & & 2,32 \\
\hline Rhinolophus lepidus & Rhinolophidae & & 163 \\
\hline Rhinolophus lobatus & Rhinolophidae & Rhinacovirus & 3 \\
\hline Rhinolophus macrotis & Rhinolophidae & $\begin{array}{l}\text { Rhinacovirus } \\
\text { Sarbecovirus }\end{array}$ & $17,43,83,91,145$ \\
\hline Rhinolophus malayanus & Rhinolophidae & $\begin{array}{l}\text { Rhinacovirus } \\
\text { Sarbecovirus }\end{array}$ & $96,152,169,174$ \\
\hline Rhinolophus marshalli & Rhinolophidae & Sarbecovirus & 169 \\
\hline Rhinolophus megaphyllus & Rhinolophidae & & 33 \\
\hline Rhinolophus mehelyi & Rhinolophidae & Sarbecovirus & 45,163 \\
\hline Rhinolophus monoceros & Rhinolophidae & Sarbecovirus & $14,17,97$ \\
\hline
\end{tabular}




\begin{tabular}{|c|c|c|c|}
\hline Bat species & Bat family & $\begin{array}{l}\text { Key coronavirus } \\
\text { subgenera }\end{array}$ & Reference \\
\hline Rhinolophus pearsonii & Rhinolophidae & $\begin{array}{l}\text { Rhinacovirus } \\
\text { Sarbecovirus }\end{array}$ & $17,43,91,174$ \\
\hline Rhinolophus pusillus & Rhinolophidae & $\begin{array}{l}\text { Rhinacovirus } \\
\text { Sarbecovirus }\end{array}$ & $\begin{array}{l}17,31,46,49,82,83,93,98,99,145,152,153,163,169 \\
, 174\end{array}$ \\
\hline Rhinolophus rex & Rhinolophidae & $\begin{array}{l}\text { Rhinacovirus } \\
\text { Sarbecovirus }\end{array}$ & $1,17,82$ \\
\hline Rhinolophus rhodesiae & Rhinolophidae & Rhinacovirus & 3 \\
\hline Rhinolophus rufus & Rhinolophidae & Nobecovirus & 5 \\
\hline Rhinolophus shameli & Rhinolophidae & $\begin{array}{l}\text { Rhinacovirus } \\
\text { Sarbecovirus }\end{array}$ & $1,9,27,83,150$ \\
\hline Rhinolophus sinicus & Rhinolophidae & $\begin{array}{l}\text { Nobecovirus } \\
\text { Rhinacovirus } \\
\text { Sarbecovirus }\end{array}$ & $\begin{array}{l}1,12,17,23,30,31,38,40,43,82,83,100- \\
109,145,147,152,159,163,173,174\end{array}$ \\
\hline Rhinolophus stheno & Rhinolophidae & $\begin{array}{l}\text { Rhinacovirus } \\
\text { Sarbecovirus }\end{array}$ & $29,152,161$ \\
\hline Rhinolophus thomasi & Rhinolophidae & $\begin{array}{l}\text { Rhinacovirus } \\
\text { Sarbecovirus }\end{array}$ & 17,163 \\
\hline Rhinolophus trifoliatus & Rhinolophidae & & 18,163 \\
\hline Rhinonicteris aurantia & Rhinonycteridae & Hibecovirus & 33 \\
\hline Triaenops afer & Rhinonycteridae & Setracovirus & $1,3,32,142$ \\
\hline Triaenops menamena & Rhinonycteridae & & 3 \\
\hline Triaenops persicus & Rhinonycteridae & $\begin{array}{l}\text { Merbecovirus } \\
\text { Nobecovirus } \\
\text { Setracovirus }\end{array}$ & $1,6,142$ \\
\hline Rhinopoma hardwickii & Rhinopomatidae & $\begin{array}{l}\text { Nobecovirus } \\
\text { Sarbecovirus }\end{array}$ & 10,163 \\
\hline Bauerus dubiaquercus & Vespertilionidae & & 1 \\
\hline Chalinolobus gouldii & Vespertilionidae & & 110 \\
\hline Chalinolobus morio & Vespertilionidae & & 110 \\
\hline Corynorhinus townsendii & Vespertilionidae & & 154 \\
\hline Eptesicus fuscus & Vespertilionidae & & $56,111-113,149$ \\
\hline Eptesicus isabellinus & Vespertilionidae & Merbecovirus & 42 \\
\hline Eptesicus nilssonii & Vespertilionidae & Merbecovirus & 114 \\
\hline Eptesicus serotinus & Vespertilionidae & Merbecovirus & $8,92,98,115,116,171$ \\
\hline Glauconycteris poensis & Pteropodidae & & 163 \\
\hline Glauconycteris variegata & Pteropodidae & Nobecovirus & 163 \\
\hline Falsistrellus mackenziei & Vespertilionidae & & 110 \\
\hline Hypsugo alaschanicus & Vespertilionidae & & 140,171 \\
\hline Hypsugo pulveratus & Vespertilionidae & Merbecovirus & 101,159 \\
\hline Hypsugo savii & Vespertilionidae & Merbecovirus & $42,94,117$ \\
\hline la io & Vespertilionidae & Merbecovirus & $1,118,145$ \\
\hline Kerivoula hardwickii & Vespertilionidae & & 163 \\
\hline Kerivoula pellucida & Vespertilionidae & & 163 \\
\hline Kerivoula titania & Vespertilionidae & & 14 \\
\hline Murina cyclotis & Vespertilionidae & & 152 \\
\hline Murina leucogaster & Vespertilionidae & & 17,23 \\
\hline Murina recondita & Vespertilionidae & & 14 \\
\hline Myotis adversus & Vespertilionidae & & 174 \\
\hline Myotis aurascens & Vespertilionidae & & 171 \\
\hline
\end{tabular}




\begin{tabular}{|c|c|c|c|}
\hline Bat species & Bat family & $\begin{array}{l}\text { Key coronavirus } \\
\text { subgenera }\end{array}$ & Reference \\
\hline Myotis bechsteinii & Vespertilionidae & & 119,120 \\
\hline $\begin{array}{l}\text { Myotis blythii } \\
\text { (includes Myotis } \\
\text { oxygnathus) }\end{array}$ & Vespertilionidae & & $42,89,115$ \\
\hline Myotis bombinus & Vespertilionidae & & 140 \\
\hline Myotis brandtii & Vespertilionidae & & 114 \\
\hline Myotis californicus & Vespertilionidae & & 1 \\
\hline Myotis capaccinii & Vespertilionidae & & 8 \\
\hline Myotis chinensis & Vespertilionidae & & 145,174 \\
\hline Myotis dasycneme & Vespertilionidae & & $116,120,121,167$ \\
\hline Myotis daubentonii & Vespertilionidae & $\begin{array}{l}\text { Merbecovirus } \\
\text { Rhinacovirus }\end{array}$ & $1,8,23,29,31,42,86,89,114,116,120-122,163,167$ \\
\hline Myotis davidii & Vespertilionidae & & 17 \\
\hline Myotis emarginatus & Vespertilionidae & & 41,90 \\
\hline Myotis evotis & Vespertilionidae & & 113 \\
\hline Myotis fimbriatus & Vespertilionidae & & $14,98,163$ \\
\hline $\begin{array}{l}\text { Myotis formosus } \\
\text { (formerly Myotis flavus) }\end{array}$ & Vespertilionidae & & 14 \\
\hline Myotis horsfieldii & Vespertilionidae & Nobecovirus & $1,27,145,163$ \\
\hline Myotis ikonnikovi & Vespertilionidae & Merbecovirus & 171 \\
\hline Myotis laniger & Vespertilionidae & Rhinacovirus & 152,163 \\
\hline Myotis longipes & Vespertilionidae & & 1,174 \\
\hline Myotis lucifugus & Vespertilionidae & & $113,123,124,125$ \\
\hline Myotis macrodactylus & Vespertilionidae & & 140,171 \\
\hline Myotis macropus & Vespertilionidae & & 33,126 \\
\hline Myotis muricola & Vespertilionidae & & 152 \\
\hline Myotis myotis & Vespertilionidae & & $1,8,42,86,89,127,157$ \\
\hline Myotis nattereri & Vespertilionidae & & $8,41,86,89,116,119,122$ \\
\hline Myotis nigricans & Vespertilionidae & & 51 \\
\hline Myotis occultus & Vespertilionidae & & 111 \\
\hline Myotis pequinius & Vespertilionidae & Merbecovirus & 98 \\
\hline Myotis petax & Vespertilionidae & & 140,171 \\
\hline $\begin{array}{l}\text { Myotis pilosus } \\
\text { (formerly Myotis ricketti) }\end{array}$ & Vespertilionidae & $\begin{array}{l}\text { Merbecovirus } \\
\text { Rhinacovirus }\end{array}$ & $1,31,38,43,46,98,145,163,174$ \\
\hline Myotis punicus & Vespertilionidae & & 8 \\
\hline Myotis riparius & Vespertilionidae & & 51 \\
\hline Myotis siligorensis & Vespertilionidae & $\begin{array}{l}\text { Merbecovirus } \\
\text { Rhinacovirus }\end{array}$ & $17,163,174$ \\
\hline Myotis velifer & Vespertilionidae & & 1,56 \\
\hline Myotis volans & Vespertilionidae & & 113 \\
\hline Myotis welwitschii & Vespertilionidae & & 163 \\
\hline Neoromicia capensis & Vespertilionidae & Merbecovirus & $7,128,129$ \\
\hline Neoromicia cf. zuluensis & Vespertilionidae & Merbecovirus & 130 \\
\hline Neoromicia somalica & Vespertilionidae & Nobecovirus & 163 \\
\hline Nyctalus lasiopterus & Vespertilionidae & & 42 \\
\hline Nyctalus leisleri & Vespertilionidae & & 45 \\
\hline Nyctalus noctula & Vespertilionidae & Merbecovirus & $94,121,157$ \\
\hline Nyctalus plancyi & Vespertilionidae & & 1,31 \\
\hline
\end{tabular}




\begin{tabular}{|c|c|c|c|}
\hline Bat species & Bat family & $\begin{array}{l}\text { Key coronavirus } \\
\text { subgenera }\end{array}$ & Reference \\
\hline \multicolumn{4}{|l|}{$\begin{array}{l}\text { (includes Nyctalus } \\
\text { velutinus) }\end{array}$} \\
\hline Nyctophilus geoffroyi & Vespertilionidae & & 110 \\
\hline Nyctophilus gouldi & Vespertilionidae & & 110 \\
\hline Perimyotis subflavus & Vespertilionidae & & 131 \\
\hline Pipistrellus abramus & Vespertilionidae & $\begin{array}{l}\text { Merbecovirus } \\
\text { Nobecovirus } \\
\text { Sarbecovirus }\end{array}$ & $31,38,43,92,101,118,132,145,171,174$ \\
\hline Pipistrellus cf. hesperidus & Vespertilionidae & Merbecovirus & 6,133 \\
\hline Pipistrellus coromandra & Vespertilionidae & Merbecovirus & $1,27,163$ \\
\hline Pipistrellus hesperidus & Vespertilionidae & Merbecovirus & 1,163 \\
\hline Pipistrellus inexspectatus & Vespertilionidae & & 172 \\
\hline $\begin{array}{l}\text { Pipistrellus kuhlii } \\
\text { (includes Pipistrellus } \\
\text { deserti) }\end{array}$ & Vespertilionidae & $\begin{array}{l}\text { Merbecovirus } \\
\text { Nobecovirus }\end{array}$ & $10,42,78,89,94,117,134,168$ \\
\hline Pipistrellus nathusii & Vespertilionidae & Merbecovirus & $59,119,120$ \\
\hline Pipistrellus pipistrellus & Vespertilionidae & Merbecovirus & $1,41,43,59,89,118,121,135,157,166$ \\
\hline Pipistrellus pygmaeus & Vespertilionidae & Merbecovirus & $59,86,116,119,120,167$ \\
\hline $\begin{array}{l}\text { Pipistrellus tenuis } \\
\text { (formerly Pipistrellus } \\
\text { minus) }\end{array}$ & Vespertilionidae & Merbecovirus & 118 \\
\hline Plecotus auritus & Vespertilionidae & $\begin{array}{l}\text { Merbecovirus } \\
\text { Sarbecovirus }\end{array}$ & 57,89 \\
\hline Plecotus taivanus & Vespertilionidae & & 14 \\
\hline Scotophilus dinganii & Vespertilionidae & Nobecovirus & $1,32,142,172$ \\
\hline Scotophilus heathii & Vespertilionidae & Nobecovirus & $9,26,163,174$ \\
\hline Scotophilus kuhlii & Vespertilionidae & Nobecovirus & $1,9,14,27,43,97,136,137,145,147,163,174$ \\
\hline Scotophilus leucogaster & Vespertilionidae & Nobecovirus & 1,172 \\
\hline Scotophilus nux & Vespertilionidae & & $1,163,172$ \\
\hline Submyotodon latirostris & Vespertilionidae & & 14 \\
\hline Tylonycteris pachypus & Vespertilionidae & $\begin{array}{l}\text { Merbecovirus } \\
\text { Rhinacovirus }\end{array}$ & $1,31,38,43,46,101,118,132,145,155,159,163,174$ \\
\hline Tylonycteris robustula & Vespertilionidae & Rhinacovirus & 101,174 \\
\hline Vespadelus baverstocki & Vespertilionidae & & 110 \\
\hline Vespadelus pumilus & Vespertilionidae & & 33 \\
\hline Vespadelus regulus & Vespertilionidae & & 110 \\
\hline Vespertilio murinus & Vespertilionidae & Merbecovirus & 157 \\
\hline $\begin{array}{l}\text { Vespertilio sinensis } \\
\text { (formerly Vespertilio } \\
\text { superans) }\end{array}$ & Vespertilionidae & $\begin{array}{l}\text { Merbecovirus } \\
\text { Hibecovirus }\end{array}$ & $1,31,92,118,138,145,171$ \\
\hline
\end{tabular}

\section{References}

1. Anthony, S. J. et al. Global patterns in coronavirus diversity. Virus Evol. 3, vex012 (2017).

2. Waruhiu, C. et al. Molecular detection of viruses in Kenyan bats and discovery of novel astroviruses, caliciviruses and rotaviruses. Virol. Sin. 32, 101-114 (2017).

3. Joffrin, L. et al. Bat coronavirus phylogeography in the Western Indian Ocean. Sci. Rep. 10, 6873 (2020). 
4. Nziza, J. et al. Coronaviruses detected in bats in close contact with humans in Rwanda. EcoHealth 17, 152-159 (2020).

5. Tsuda, S. et al. Genomic and serological detection of bat coronavirus from bats in the Philippines. Arch. Virol. 157, 2349-2355 (2012).

6. Montecino-Latorre, D. et al. Reproduction of East-African bats may guide risk mitigation for coronavirus spillover. One Heal. Outlook 2, 2 (2020).

7. Geldenhuys, M., Weyer, J., Nel, L. H. \& Markotter, W. Coronaviruses in South African bats. VectorBorne Zoonotic Dis. 13, 516-519 (2013).

8. Ar Gouilh, M. et al. SARS-CoV related Betacoronavirus and diverse Alphacoronavirus members found in western old-world. Virology 517, 88-97 (2018).

9. Wacharapluesadee, S. et al. Diversity of coronavirus in bats from Eastern Thailand. Virol. J. 12, 57 (2015).

10. Memish, Z. A. et al. Middle East respiratory syndrome coronavirus in bats, Saudi Arabia. Emerg. Infect. Dis. 19, 1819-1823 (2013).

11. Mishra, N. et al. A viral metagenomic survey identifies known and novel mammalian viruses in bats from Saudi Arabia. PLoS One 14, e0214227 (2019).

12. Hu, B. et al. Discovery of a rich gene pool of bat SARS-related coronaviruses provides new insights into the origin of SARS coronavirus. PLOS Pathog. 13, e1006698 (2017).

13. Corman, V. M. et al. Evidence for an ancestral association of human coronavirus 229E with bats. J. Virol. 89, 11858-11870 (2015).

14. Chen, Y.-N. et al. Detection of the severe acute respiratory syndrome-related coronavirus and alphacoronavirus in the bat population of Taiwan. Zoonoses Public Health 63, 608-615 (2016).

15. Ar Gouilh, M. et al. SARS-coronavirus ancestor's foot-prints in South-East Asian bat colonies and the refuge theory. Infect. Genet. Evol. 11, 1690-1702 (2011).

16. Ge, X. et al. Metagenomic analysis of viruses from bat fecal samples reveals many novel viruses in insectivorous bats in China. J. Virol. 86, 4620-4630 (2012).

17. Lin, X.-D. et al. Extensive diversity of coronaviruses in bats from China. Virology 507, 1-10 (2017).

18. Seltmann, A. et al. Seasonal fluctuations of astrovirus, but not coronavirus shedding in bats inhabiting human-modified tropical forests. EcoHealth 14, 272-284 (2017).

19. Bourgarel, M. et al. Circulation of alphacoronavirus, betacoronavirus and paramyxovirus in Hipposideros bat species in Zimbabwe. Infect. Genet. Evol. 58, 253-257 (2018).

20. Maganga, G. D. et al. Bat distribution size or shape as determinant of viral richness in African bats. PLoS One 9, e100172 (2014).

21. Pfefferle, S. et al. Distant relatives of severe acute respiratory syndrome coronavirus and close relatives of human coronavirus $229 \mathrm{E}$ in bats, Ghana. Emerg. Infect. Dis. 15, 1377-1384 (2009).

22. Maganga, G. D. et al. Genetic diversity and ecology of coronaviruses hosted by cave-dwelling bats in Gabon. Sci. Rep. 10, 7314 (2020).

23. $\mathrm{Xu}$, L. et al. Detection and characterization of diverse alpha- and betacoronaviruses from bats in China. Virol. Sin. 31, 69-77 (2016).

24. Tong, S. et al. Detection of novel SARS-like and other coronaviruses in bats from Kenya. Emerg. Infect. Dis. 15, 482-485 (2009).

25. Quan, P.-L. et al. Identification of a severe acute respiratory syndrome coronavirus-like virus in a leaf-nosed bat in Nigeria. MBio 1, e00208-10 (2010).

26. Valitutto, M. T. et al. Detection of novel coronaviruses in bats in Myanmar. PLoS One 15, e0230802 (2020).

27. Lacroix, A. et al. Genetic diversity of coronaviruses in bats in Lao PDR and Cambodia. Infect. Genet. Evol. 48, 10-18 (2017). 
28. Lau, S. K. P. et al. Recent transmission of a novel alphacoronavirus, bat coronavirus HKU10, from Leschenault's rousettes to Pomona leaf-nosed bats: first evidence of interspecies transmission of coronavirus between bats of different suborders. J. Virol. 86, 11906-11918 (2012).

29. Lau, S. K. P. et al. Severe acute respiratory syndrome (SARS) coronavirus ORF8 protein is acquired from SARS-related coronavirus from greater horseshoe bats through recombination. J. Virol. 89, 10532-10547 (2015).

30. Ge, X.-Y. et al. Coexistence of multiple coronaviruses in several bat colonies in an abandoned mineshaft. Virol. Sin. 31, 31-40 (2016).

31. Wu, Z. et al. Deciphering the bat virome catalog to better understand the ecological diversity of bat viruses and the bat origin of emerging infectious diseases. ISME J. 10, 609-620 (2016).

32. Tao, Y. et al. Surveillance of bat coronaviruses in Kenya identifies relatives of human coronaviruses NL63 and 229E and their recombination history. J. Virol. 91, e01953-16 (2017).

33. Smith, C. S. et al. Coronavirus infection and diversity in bats in the Australasian region. EcoHealth 13, 72-82 (2016).

34. Shirato, K. et al. Detection of bat coronaviruses from Miniopterus fuliginosus in Japan. Virus Genes 44, 40-44 (2012).

35. Du, J. et al. Genetic diversity of coronaviruses in Miniopterus fuliginosus bats. Sci. China Life Sci. 59, 604-614 (2016).

36. Chu, D. K. W. et al. Coronaviruses in bent-winged bats (Miniopterus spp.). J. Gen. Virol. 87, 24612466 (2006).

37. Poon, L. L. M. et al. Identification of a novel coronavirus in bats. J. Virol. 79, 2001-2009 (2005).

38. Woo, P. C. Y. et al. Molecular diversity of coronaviruses in bats. Virology 351, 180-187 (2006).

39. Chu, D. K. W., Peiris, J. S. M., Chen, H., Guan, Y. \& Poon, L. L. M. Genomic characterizations of bat coronaviruses (1A, 1B and HKU8) and evidence for co-infections in Miniopterus bats. J. Gen. Virol. 89, 1282-1287 (2008).

40. Woo, P. C. Y. et al. Comparative analysis of twelve genomes of three novel group $2 \mathrm{c}$ and group $2 \mathrm{~d}$ coronaviruses reveals unique group and subgroup features. J. Virol. 81, 1574-1585 (2007).

41. Monchatre-Leroy, E. et al. Identification of alpha and beta coronavirus in wildlife species in France: bats, rodents, rabbits, and hedgehogs. Viruses 9, 364 (2017).

42. Falcón, A. et al. Detection of alpha and betacoronaviruses in multiple Iberian bat species. Arch. Virol. 156, 1883-1890 (2011).

43. Tang, X. C. et al. Prevalence and genetic diversity of coronaviruses in bats from China. J. Virol. 80, 7481-7490 (2006).

44. Kim, H. K. et al. Detection of severe acute respiratory syndrome-like, Middle East respiratory syndrome-like bat coronaviruses and group $\mathrm{H}$ rotavirus in faeces of Korean bats. Transbound. Emerg. Dis. 63, 365-372 (2016).

45. Drexler, J. F. et al. Genomic characterization of severe acute respiratory syndrome-related coronavirus in European bats and classification of coronaviruses based on partial RNA-dependent RNA polymerase gene sequences. J. Virol. 84, 11336-11349 (2010).

46. Liang, J. et al. Detection of diverse viruses in alimentary specimens of bats in Macau. Virol. Sin. 32, 226-234 (2017).

47. Wu, Z. et al. Virome analysis for identification of novel mammalian viruses in bat species from Chinese provinces. J. Virol. 86, 10999-11012 (2012).

48. Wacharapluesadee, S. et al. Group C betacoronavirus in bat guano fertilizer, Thailand. Emerg. Infect. Dis. 19, 349-1352 (2013).

49. Yang, L. et al. Novel SARS-like betacoronaviruses in bats, China, 2011. Emerg. Infect. Dis. 19, 989991 (2013). 
50. Asano, K. M. et al. Alphacoronavirus in urban Molossidae and Phyllostomidae bats, Brazil. Virol. J. 13, 110 (2016).

51. Góes, L. G. B. et al. Genetic diversity of bats coronaviruses in the Atlantic forest hotspot biome, Brazil. Infect. Genet. Evol. 44, 510-513 (2016).

52. Corman, V. M. et al. Highly diversified coronaviruses in neotropical bats. J. Gen. Virol. 94, 19841994 (2013).

53. Lima, F. E. de S. et al. Detection of Alphacoronavirus in velvety free-tailed bats (Molossus molossus) and Brazilian free-tailed bats (Tadarida brasiliensis) from urban area of Southern Brazil. Virus Genes 47, 164-167 (2013).

54. Góes, L. G. B. et al. Novel bat coronaviruses, Brazil and Mexico. Emerg. Infect. Dis. 19, 1711-1713 (2013).

55. Bittar, C. et al. Alphacoronavirus detection in lungs, liver, and intestines of bats from Brazil. Microb. Ecol. 79, 203-212 (2020).

56. Anthony, S. J. et al. Coronaviruses in bats from Mexico. J. Gen. Virol. 94, 1028-1038 (2013).

57. Lecis, R., Mucedda, M., Pidinchedda, E., Pittau, M. \& Alberti, A. Molecular identification of Betacoronavirus in bats from Sardinia (Italy): first detection and phylogeny. Virus Genes 55, 60-67 (2019).

58. Hall, R. J. et al. New alphacoronavirus in Mystacina tuberculata bats, New Zealand. Emerg. Infect. Dis. 20, 697-700 (2014).

59. Annan, A. et al. Human betacoronavirus 2c EMC/2012-related viruses in bats, Ghana and Europe. Emerg. Infect. Dis. 19, 456-459 (2013).

60. Moreira-Soto, A. et al. Neotropical bats from Costa Rica harbour diverse coronaviruses. Zoonoses Public Health 62, 501-505 (2015).

61. Carrington, C. V. F. et al. Detection and phylogenetic analysis of group 1 coronaviruses in South American bats. Emerg. Infect. Dis. 14, 1890-1893 (2008).

62. Brandão, P. E. et al. A coronavirus detected in the vampire bat Desmodus rotundus. Brazilian J. Infect. Dis. 12, 466-468 (2008).

63. Bergner, L. M. et al. Demographic and environmental drivers of metagenomic viral diversity in vampire bats. Mol. Ecol. 29, 26-39 (2020).

64. Watanabe, S. et al. Bat coronaviruses and experimental infection of bats, the Philippines. Emerg. Infect. Dis. 16, 1217-1223 (2010).

65. Lim, X. F. et al. Detection and characterization of a novel bat-borne coronavirus in Singapore using multiple molecular approaches. J. Gen. Virol. 100, 1363-1374 (2019).

66. Anindita, P. D. et al. Detection of coronavirus genomes in Moluccan naked-backed fruit bats in Indonesia. Arch. Virol. 160, 1113-1118 (2015).

67. Razanajatovo, N. H. et al. Detection of new genetic variants of betacoronaviruses in endemic frugivorous bats of Madagascar. Virol. J. 12, 42 (2015).

68. Leopardi, S. et al. The close genetic relationship of lineage D Betacoronavirus from Nigerian and Kenyan straw-colored fruit bats (Eidolon helvum) is consistent with the existence of a single epidemiological unit across sub-Saharan Africa. Virus Genes 52, 573-577 (2016).

69. Mendenhall, I. H. et al. Identification of a lineage D betacoronavirus in cave nectar bats (Eonycteris spelaea) in Singapore and an overview of lineage D reservoir ecology in SE Asian bats. Transbound. Emerg. Dis. 64, 1790-1800 (2017).

70. Paskey, A. C. et al. The temporal RNA virome patterns of a lesser dawn bat (Eonycteris spelaea) colony revealed by deep sequencing. Virus Evol. 6, 1-14 (2020).

71. Luo, Y. et al. Longitudinal surveillance of betacoronaviruses in fruit bats in Yunnan province, China during 2009-2016. Virol. Sin. 33, 87-95 (2018). 
72. Tampon, N. V. T. et al. First molecular evidence for bat betacoronavirus in Mindanao. Philipp. J. Sci. 149, 109-112 (2020).

73. Febriani, W. D. et al. Bat coronavirus of Pteropus alecto from Gorontalo province, Indonesia. Int. J. Trop. Vet. Biomed. Res. 3, 36-42 (2018).

74. Wacharapluesadee, S. et al. Longitudinal study of age-specific pattern of coronavirus infection in Lyle's flying fox (Pteropus lylei) in Thailand. Virol. J. 15, 38 (2018).

75. Anthony, S. J. et al. A strategy to estimate unknown viral diversity in mammals. MBio 4, e00598-13 (2013).

76. Yadav, P. D. et al. Detection of coronaviruses in Pteropus \& Rousettus species of bats from different States of India. Indian J. Med. Res. 151, 226-235 (2020).

77. Kudagammana, H. D. W. S. et al. Coronaviruses in guano from Pteropus medius bats in Peradeniya, Sri Lanka. Transbound. Emerg. Dis. 65, 1122-1124 (2018).

78. Shehata, M. M. et al. Surveillance for coronaviruses in bats, Lebanon and Egypt, 2013-2015. Emerg. Infect. Dis. 22, 148-150 (2016).

79. Obameso, J. O. et al. The persistent prevalence and evolution of cross-family recombinant coronavirus GCCDC1 among a bat population: a two-year follow-up. Sci. China Life Sci. 60, 13571363 (2017).

80. Huang, C. et al. A bat-derived putative cross-family recombinant coronavirus with a reovirus gene. PLOS Pathog. 12, e1005883 (2016).

81. Lau, S. K. P. et al. Coexistence of different genotypes in the same bat and serological characterization of Rousettus bat coronavirus HKU9 belonging to a novel betacoronavirus subgroup. J. Virol. 84, 11385-11394 (2010).

82. Zhou, P. et al. Fatal swine acute diarrhoea syndrome caused by an HKU2-related coronavirus of bat origin. Nature 556, 255-258 (2018).

83. Wang, N. et al. Characterization of a new member of alphacoronavirus with unique genomic features in Rhinolophus bats. Viruses 11, 379 (2019).

84. Markotter, W. et al. Paramyxo- and coronaviruses in Rwandan bats. Trop. Med. Infect. Dis. 4, 99 (2019).

85. Suzuki, J., Sato, R., Kobayashi, T., Aoi, T. \& Harasawa, R. Group B betacoronavirus in rhinolophid bats, Japan. J. Vet. Med. Sci. 76, 1267-1269 (2014).

86. Kemenesi, G. et al. Molecular survey of RNA viruses in Hungarian bats: discovering novel astroviruses, coronaviruses, and caliciviruses. Vector-Borne Zoonotic Dis. 14, 846-855 (2014).

87. Balboni, A., Palladini, A., Bogliani, G. \& Battilani, M. Detection of a virus related to betacoronaviruses in Italian greater horseshoe bats. Epidemiol. Infect. 139, 216-219 (2011).

88. Balboni, A., Gallina, L., Palladini, A., Prosperi, S. \& Battilani, M. A real-time PCR assay for bat SARSlike coronavirus detection and its application to Italian greater horseshoe bat faecal sample surveys. Sci. World J. 2012, 1-8 (2012).

89. Rizzo, F. et al. Coronavirus and paramyxovirus in bats from Northwest Italy. BMC Vet. Res. 13, 396 (2017).

90. Pauly, M. et al. Novel alphacoronaviruses and paramyxoviruses cocirculate with type 1 and severe acute respiratory system (SARS)-related betacoronaviruses in synanthropic bats of Luxembourg. Appl. Environ. Microbiol. 83, e01326-17 (2017).

91. Li, W. et al. Bats are natural reservoirs of SARS-like coronaviruses. Science. 310, 676-679 (2005).

92. Lee, S. et al. Genetic characteristics of coronaviruses from Korean bats in 2016. Microb. Ecol. 75, 174-182 (2018).

93. Hu, D. et al. Virome analysis for identification of novel mammalian viruses in bats from Southeast China. Sci. Rep. 7, 10917 (2017). 
94. Lelli, D. et al. Detection of coronaviruses in bats of various species in Italy. Viruses 5, 2679-2689 (2013).

95. Rihtarič, D., Hostnik, P., Steyer, A., Grom, J. \& Toplak, I. Identification of SARS-like coronaviruses in horseshoe bats (Rhinolophus hipposideros) in Slovenia. Arch. Virol. 155, 507-514 (2010).

96. Zhou, H. et al. A novel bat coronavirus closely related to SARS-CoV-2 contains natural insertions at the S1/S2 cleavage site of the spike protein. Curr. Biol. 30, 1-8 (2020).

97. Chen, Y.-N., Su, B.-G., Chen, H.-C., Chou, C.-H. \& Cheng, H.-C. Detection of specific antibodies to the nucleocapsid protein fragments of severe acute respiratory syndrome-coronavirus and Scotophilus bat coronavirus-512 in three insectivorous bat species. Taiwan Vet. J. 44, 179-188 (2018).

98. Han, H.-J. et al. Novel coronaviruses, astroviruses, adenoviruses and circoviruses in insectivorous bats from northern China. Zoonoses Public Health 64, 636-646 (2017).

99. Wang, L. et al. Discovery and genetic analysis of novel coronaviruses in least horseshoe bats in southwestern China. Emerg. Microbes Infect. 6, 1-8 (2017).

100. Lau, S. K. P. et al. Severe acute respiratory syndrome coronavirus-like virus in Chinese horseshoe bats. Proc. Natl. Acad. Sci. 102, 14040-14045 (2005).

101. Lau, S. K. P. et al. Receptor usage of a novel bat lineage $\mathrm{C}$ betacoronavirus reveals evolution of Middle East respiratory syndrome-related coronavirus spike proteins for human dipeptidyl peptidase 4 binding. J. Infect. Dis. 218, 197-207 (2018).

102. Hu, D. et al. Genomic characterization and infectivity of a novel SARS-like coronavirus in Chinese bats. Emerg. Microbes Infect. 7, 1-10 (2018).

103. Lau, S. K. P. et al. Complete genome sequence of bat coronavirus HKU2 from Chinese horseshoe bats revealed a much smaller spike gene with a different evolutionary lineage from the rest of the genome. Virology 367, 428-439 (2007).

104. Lau, S. K. P. et al. Ecoepidemiology and complete genome comparison of different strains of severe acute respiratory syndrome-related Rhinolophus bat coronavirus in China reveal bats as a reservoir for acute, self-limiting infection that allows recombination events. J. Virol. 84, 2808-2819 (2010).

105. Ge, X.-Y. et al. Isolation and characterization of a bat SARS-like coronavirus that uses the ACE2 receptor. Nature 503, 535-538 (2013).

106. Wang, M.-N. et al. Longitudinal surveillance of SARS-like coronaviruses in bats by quantitative realtime PCR. Virol. Sin. 31, 78-80 (2016).

107. Yang, X.-L. et al. Isolation and characterization of a novel bat coronavirus closely related to the direct progenitor of severe acute respiratory syndrome coronavirus. J. Virol. 90, 3253-3256 (2016).

108. Yuan, J. et al. Intraspecies diversity of SARS-like coronaviruses in Rhinolophus sinicus and its implications for the origin of SARS coronaviruses in humans. J. Gen. Virol. 91, 1058-1062 (2010).

109. Yuen, K. Y., Lau, S. K. P. \& Woo, P. C. Y. Wild animal surveillance for coronavirus HKU1 and potential variants of other coronaviruses. Hong Kong Med. J. 18, S25-S26 (2012).

110. Prada, D., Boyd, V., Baker, M. L., O’Dea, M. \& Jackson, B. Viral diversity of microbats within the south west botanical province of Western Australia. Viruses 11, 1157 (2019).

111. Dominguez, S. R., O'Shea, T. J., Oko, L. M. \& Holmes, K. V. Detection of group 1 coronaviruses in bats in North America. Emerg. Infect. Dis. 13, 1295-1300 (2007).

112. Donaldson, E. F. et al. Metagenomic analysis of the viromes of three North American bat species: viral diversity among different bat species that share a common habitat. J. Virol. 84, 13004-13018 (2010).

113. Osborne, C. et al. Alphacoronaviruses in New World bats: prevalence, persistence, phylogeny, and potential for interaction with humans. PLoS One 6, e19156 (2011). 
114. Kivistö, I. et al. First report of coronaviruses in northern European bats. Vector-Borne Zoonotic Dis. 20, 155-158 (2020).

115. De Benedictis, P. et al. Alpha and lineage C betaCoV infections in Italian bats. Virus Genes 48, 366371 (2014).

116. Lazov, C. et al. Detection and characterization of distinct alphacoronaviruses in five different bat species in Denmark. Viruses 10, 486 (2018).

117. Moreno, A. et al. Detection and full genome characterization of two beta CoV viruses related to Middle East respiratory syndrome from bats in Italy. Virol. J. 14, 239 (2017).

118. Luo, C.-M. et al. Discovery of novel bat coronaviruses in South China that use the same receptor as Middle East respiratory syndrome coronavirus. J. Virol. 92, e00116-18 (2018).

119. Fischer, K. et al. Insectivorous bats carry host specific astroviruses and coronaviruses across different regions in Germany. Infect. Genet. Evol. 37, 108-116 (2016).

120. Gloza-Rausch, F. et al. Detection and prevalence patterns of group I coronaviruses in bats, northern Germany. Emerg. Infect. Dis. 14, 626-631 (2008).

121. Reusken, C. B. E. M. et al. Circulation of group 2 coronaviruses in a bat species common to urban areas in western Europe. Vector-Borne Zoonotic Dis. 10, 785-791 (2010).

122. August, T. A., Mathews, F. \& Nunn, M. A. Alphacoronavirus detected in bats in the United Kingdom. Vector-Borne Zoonotic Dis. 12, 530-533 (2012).

123. Misra, V. et al. Detection of polyoma and corona viruses in bats of Canada. J. Gen. Virol. 90, 20152022 (2009).

124. Subudhi, S. et al. A persistently infecting coronavirus in hibernating Myotis lucifugus, the North American little brown bat. J. Gen. Virol. 98, 2297-2309 (2017).

125. Davy, C. M. et al. White-nose syndrome is associated with increased replication of a naturally persisting coronaviruses in bats. Sci. Rep. 8, 15508 (2018).

126. Jeong, J. et al. Persistent infections support maintenance of a coronavirus in a population of Australian bats (Myotis macropus). Epidemiol. Infect. 145, 2053-2061 (2017).

127. Drexler, J. F. et al. Amplification of emerging viruses in a bat colony. Emerg. Infect. Dis. 17, 449456 (2011).

128. Corman, V. M. et al. Rooting the phylogenetic tree of Middle East respiratory syndrome coronavirus by characterization of a conspecific virus from an African bat. J. Virol. 88, 1129711303 (2014).

129. Geldenhuys, M. et al. A metagenomic viral discovery approach identifies potential zoonotic and novel mammalian viruses in Neoromicia bats within South Africa. PLoS One 13, e0194527 (2018).

130. Ithete, N. L. et al. Close relative of human Middle East respiratory syndrome coronavirus in bat, South Africa. Emerg. Infect. Dis. 19, 1697-1699 (2013).

131. Huynh, J. et al. Evidence supporting a zoonotic origin of human coronavirus strain NL63. J. Virol. 86, 12816-12825 (2012).

132. Lau, S. K. P. et al. Genetic characterization of betacoronavirus lineage $C$ viruses in bats reveals marked sequence divergence in the spike protein of Pipistrellus bat coronavirus HKU5 in Japanese pipistrelle: implications for the origin of the novel Middle East respiratory syndrome coronavirus. J. Virol. 87, 8638-8650 (2013).

133. Anthony, S. J. et al. Further evidence for bats as the evolutionary source of Middle East respiratory syndrome coronavirus. MBio 8, e00373-17 (2017).

134. De Sabato, L. et al. Full genome characterization of two novel Alpha-coronavirus species from Italian bats. Virus Res. 260, 60-66 (2019).

135. Goffard, A. et al. Alphacoronaviruses detected in French bats are phylogeographically linked to coronaviruses of European bats. Viruses 7, 6279-6290 (2015). 
136. Berto, A. et al. Detection of potentially novel paramyxovirus and coronavirus viral RNA in bats and rats in the Mekong Delta region of southern Viet Nam. Zoonoses Public Health 65, 30-42 (2018).

137. Su, B.-G., Chen, H. C., Cheng, H.-C. \& Chen, Y.-N. Detection of bat coronavirus and specific antibodies in chestnut bat (Scotophilus kuhlii) population in central Taiwan. Taiwan Vet. J. 42, 1926 (2016).

138. Yang, L. et al. MERS-related betacoronavirus in Vespertilio superans bats, China. Emerg. Infect. Dis. 20, 1260-1262 (2014).

139. Wells, H. L. et al. The evolutionary history of ACE2 usage within the coronavirus subgenus Sarbecovirus. Virus Evol. 7, veab007 (2021).

140. Lo, V. T. et al. Long-term surveillance of bat coronaviruses in Korea: diversity and distribution pattern. Transbound. Emerg. Dis. tbed.13653 (2020).

141. Lacroix, A. et al. Wide diversity of coronaviruses in frugivorous and insectivorous bat species: a pilot study in Guinea, West Africa. Viruses 12, 855 (2020).

142. Kumakamba, C. et al. Coronavirus surveillance in wildlife from two Congo basin countries detects RNA of multiple species circulating in bats and rodents. PLoS One 16, e0236971 (2021).

143. Bergner, L. M., Orton, R. J. \& Streicker, D. G. Complete genome sequence of an alphacoronavirus from common vampire bats in Peru. Microbiol. Resour. Announc. 9, e00742-20 (2020).

144. Paskey, A. C. et al. Detection of recombinant Rousettus bat coronavirus GCCDC1 in lesser dawn bats (Eonycteris spelaea) in Singapore. Viruses 12, 539 (2020).

145. Latinne, A. et al. Origin and cross-species transmission of bat coronaviruses in China. Nat. Commun. 11, 4235 (2020).

146. Zhou, P. et al. A pneumonia outbreak associated with a new coronavirus of probable bat origin. Nature 579, 270-273 (2020).

147. Han, Y. et al. Identification of diverse bat alphacoronaviruses and betacoronaviruses in China provides new insights into the evolution and origin of coronavirus-related diseases. Front. Microbiol. 10, 1900 (2019).

148. Murakami, S. et al. Detection and characterization of bat sarbecovirus phylogenetically related to SARS-CoV-2, Japan. Emerg. Infect. Dis. 26, 3025-3029 (2020).

149. Hall, J. S. et al. Experimental challenge of a North American bat species, big brown bat (Eptesicus fuscus), with SARS-CoV-2. Transbound. Emerg. Dis. tbed.13949 (2021).

150. Hul, V. et al. A novel SARS-CoV-2 related coronavirus in bats from Cambodia. bioRxiv 2021.01.26.428212 (2021).

151. Wacharapluesadee, S. et al. Evidence for SARS-CoV-2 related coronaviruses circulating in bats and pangolins in Southeast Asia. Nat. Commun. 12, 972 (2021).

152. Zhou, H. et al. Identification of novel bat coronaviruses sheds light on the evolutionary origins of SARS-CoV-2 and related viruses. Cell (2021).

153. Li, L. et al. A novel SARS-CoV-2 related virus with complex recombination isolated from bats in Yunnan province, China. bioRxiv 10.1101/2021.03.17.435823 (2021).

154. Li, Y. et al. Virome of bat guano from nine Northern California roosts. J. Virol. 95, e01713-20 (2021).

155. Lau, S. K. P. et al. Isolation of MERS-related coronavirus from lesser bamboo bats that uses DPP4 and infects human-DPP4-transgenic mice. Nat. Commun. 12, 216 (2021).

156. Kia, G. S. N., Tao, Y., Umoh, J. U., Kwaga, J. K. P. \& Tong, S. Identification of coronaviruses, paramyxoviruses, reoviruses, and rotaviruses among bats in Nigeria. Am. J. Trop. Med. Hyg. 104, 1106-1110 (2021).

157. Hardmeier, I. et al. Metagenomic analysis of fecal and tissue samples from 18 endemic bat species in Switzerland revealed a diverse virus composition including potentially zoonotic viruses. PLOS One 16, e0252534 (2021). 
158. Cibulski, S. P. et al. Detection of multiple viruses in oropharyngeal samples from Brazilian freetailed bats (Tadarida brasiliensis) using viral metagenomics. Arch. Virol. 166, 207-212 (2021).

159. Lau, S. K. P., Woo, P. C. Y. \& Zheng, B. J. Molecular diversity and evolution of bat group C betacoronaviruses: origin of the novel human group $\mathrm{C}$ betacoronavirus (abridged secondary publication). Hong Kong Med. J. 27, S23-S27 (2021).

160. Alkhovsky, S. V et al. SARS-like coronaviruses in horseshoe bats (Rhinolophus spp.) in Russia, 2020. bioRxiv 17, 2021.05.17.444362 (2021).

161. Guo, H. et al. Identification of a novel lineage bat SARS-related coronaviruses that use bat ACE2 receptor. bioRxiv 2021.05.21.445091 (2021).

162. Muzeniek, T. et al. Detection of alpha- and betacoronaviruses in Miniopterus fuliginosus and Rousettus leschenaultii, two species of Sri Lankan bats. Vaccines 9, 650 (2021).

163. Grange, Z. L. et al. Ranking the risk of animal-to-human spillover for newly discovered viruses. Proc. Natl. Acad. Sci. U. S. A. 118, e2002324118 (2021).

164. Alves, R. S. et al. Detection of coronavirus in vampire bats (Desmodus rotundus) in southern Brazil. Transbound. Emerg. Dis. tbed.14150 (2021).

165. Crook, J. M. et al. Metagenomic identification of a new sarbecovirus from horseshoe bats in Europe. Sci. Rep. 11, 14723 (2021).

166. Kohl, C. et al. The virome of German bats: comparing virus discovery approaches. Sci. Rep. 11, 7430 (2021).

167. Lazov, C. M., Belsham, G. J., Bøtner, A. \& Rasmussen, T. B. Full-genome sequences of alphacoronaviruses and astroviruses from Myotis and Pipistrelle bats in Denmark. Viruses 2021, Vol. 13, Page 1073 13, 1073 (2021).

168. Leopardi, S. et al. Interface between bats and pigs in heavy pig production. Viruses 13, 4 (2020).

169. Temmam, S. et al. Coronaviruses with a SARS-CoV-2-like receptor-binding domain allowing ACE2mediated entry into human cells isolated from bats of Indochinese peninsula. Research Square (2021).

170. Dharmayanti, N. L. P. I. et al. Molecular detection of bat coronaviruses in three bat species in Indonesia. J. Vet. Sci. 22, e70 (2021).

171. Lee, S.-Y. et al. Genetic diversity of bat coronaviruses and comparative genetic analysis of MERSrelated coronaviruses in South Korea. Transbound. Emerg. Dis. (2021).

172. Ntumvi, N. F. et al. Wildlife in Cameroon harbor diverse coronaviruses including many isolates closely related to human coronavirus 229E. bioRxiv 2021.09.03.458874 (2021).

173. Wang, N. et al. Genomic characterization of diverse bat coronavirus HKU10 in Hipposideros bats. Viruses 13, 1962 (2021).

174. Wu, Z. et al. A comprehensive survey of bat sarbecoviruses across China for the origin tracing of SARS-CoV and SARS-CoV-2. Research Square (2021). 
Supplementary Table 2. Comparison of difference approaches to studying coronaviruses in bats. A total of 214 original studies on bat-associated coronaviruses were classified into study types. Study types were not exclusive, so a study may fit into multiple types depending on the sampling approach and analytical methods. All classified studies can be found in Supplementary Dataset 1.

\begin{tabular}{|c|c|c|c|c|c|}
\hline $\begin{array}{l}\text { Study type and } \\
\text { description }\end{array}$ & Number of studies & Overview & What we can learn & Advantages & Caveats \\
\hline $\begin{array}{l}\text { Experimental } \\
\text { Experimental infection } \\
\text { of individual bats or bat } \\
\text { cell lines, or other viral } \\
\text { manipulations in a } \\
\text { controlled environment }\end{array}$ & $\begin{array}{l}\text { Bat cell lines: } 29 \\
\text { Live bats: } 6\end{array}$ & $\begin{array}{l}\text { Bat cell experiments } \\
\text { - Target cells: brain, } \\
\text { embryo, intestine, } \\
\text { kidney, lung } \\
\text { - Tested viruses: } \\
\text { multiple bat SARS- } \\
\text { related CoVs, } \\
\text { BatCoV HKU4, } \\
\text { BatCoV HKU9, } \\
\text { HCoV-229E, HCoV- } \\
\text { NL63, MERS-CoV, } \\
\text { PEDV, Ro-BatCoV } \\
\text { GCCDC1, SADS- } \\
\text { CoV, SARS-CoV, } \\
\text { SARS-CoV-2, } \\
\text { Scotophilus bat CoV } \\
\text { 512, TGEV } \\
\text { Live bat experiments } \\
\text { - Tested hosts and } \\
\text { viruses: Artibeus } \\
\text { jamaicensis (MERS- } \\
\text { CoV), Eptesicus } \\
\text { fuscus (SARS-CoV- } \\
\text { 2), Myotis lucifugus } \\
\text { (Myl-CoV), } \\
\text { Rousettus } \\
\text { leschenaultii } \\
\text { (BatCoV HKU9), } \\
\text { Rousettus } \\
\text { aegyptiacus (bat } \\
\text { SARSr-CoV WIV1, } \\
\text { SARS-CoV-2) }\end{array}$ & $\begin{array}{l}\text { - Characterization of } \\
\text { newly detected } \\
\text { viruses } \\
\text { - Bat species } \\
\text { susceptibility to } \\
\text { infection and dose- } \\
\text { response } \\
\text { relationships } \\
\text { - Magnitude, quality, } \\
\text { and kinetics of } \\
\text { immune responses to } \\
\text { pathogens, and } \\
\text { mechanisms of viral } \\
\text { control or tolerance } \\
\text { - Disease pathogenesis } \\
\text { (or lack thereof) } \\
\text { - Individual and within- } \\
\text { host infection, } \\
\text { disease, and } \\
\text { immunological } \\
\text { processes, especially } \\
\text { those required for } \\
\text { dynamic modeling } \\
\text { (e.g., infectious } \\
\text { periods, acute vs. } \\
\text { latent infections, } \\
\text { waning immunity, } \\
\text { etc.) } \\
\text { - Tissue tropism and } \\
\text { routes of virus } \\
\text { excretion and } \\
\text { transmission }\end{array}$ & $\begin{array}{l}\text { - Ability to test Koch's } \\
\text { postulates using } \\
\text { different strains and } \\
\text { bat species } \\
\text { - Causal inference } \\
\text { - Controlled } \\
\text { environment } \\
\text { - Rapid technological } \\
\text { advances make } \\
\text { diagnostic tools } \\
\text { affordable } \\
\text { - Relatively rapid data } \\
\text { acquisition }\end{array}$ & $\begin{array}{l}\text { - Relies on existing viral } \\
\text { isolates; cannot } \\
\text { isolate new } \\
\text { pathogens } \\
\text { - No ecological } \\
\text { context; impossible } \\
\text { to accurately } \\
\text { replicate } \\
\text { environmental } \\
\text { conditions } \\
\text { - Lab conditions may } \\
\text { not effectively mimic } \\
\text { the environmental } \\
\text { conditions that drive } \\
\text { infections in reservoir } \\
\text { hosts } \\
\text { - Challenging and } \\
\text { expensive to house } \\
\text { and breed colonies of } \\
\text { bats } \\
\text { - Often requires } \\
\text { biosafety level } 3 \text { or } 4 \\
\text { facilities and } \\
\text { specialized training } \\
\text { - A bat is not a bat, and } \\
\text { a virus is not a virus: } \\
\text { species-specific } \\
\text { responses to } \\
\text { infection make it } \\
\text { difficult to generalize } \\
\text { across species or bat } \\
\text { families }\end{array}$ \\
\hline
\end{tabular}




\begin{tabular}{|c|c|c|c|c|c|}
\hline Study type and & Number of studies & Overview & What we can learn & Advantages & Caveats \\
\hline & & & $\begin{array}{l}\text { - Receptor binding } \\
\text { efficiency in bats and } \\
\text { other potential hosts } \\
\text { - Facilitative or } \\
\text { antagonistic } \\
\text { interactions between } \\
\text { coinfecting viruses } \\
\text { - Virus surface survival } \\
\text { and sensitivity to heat } \\
\text { or desiccation } \\
\text { - Development of } \\
\text { model systems, } \\
\text { laboratory protocols, } \\
\text { and screening tools } \\
\text { for the field } \\
\text { - Spillover potential to } \\
\text { other/novel hosts }\end{array}$ & & $\begin{array}{l}\text { - In vitro studies miss } \\
\text { differences in cell } \\
\text { recruitment and } \\
\text { localization or cell- } \\
\text { cell interaction } \\
\text { - Immortalized cells } \\
\text { behave differently } \\
\text { from primary cells or } \\
\text { cells in an in vivo } \\
\text { context } \\
\text { - Fundamental } \\
\text { knowledge of bat } \\
\text { immune systems and } \\
\text { basic tools for } \\
\text { probing bat immune } \\
\text { responses are lacking } \\
\text { Experiments are } \\
\text { usually time-limited } \\
\text { (e.g., limited ability to } \\
\text { study immune } \\
\text { function senescence, } \\
\text { viral recrudescence, } \\
\text { etc.) }\end{array}$ \\
\hline $\begin{array}{l}\text { Longitudinal } \\
\text { Repeated sampling of } \\
\text { individuals, single } \\
\text { populations, or multiple } \\
\text { populations over time; } \\
\text { ideally, this occurs in } \\
\text { closed populations with } \\
\text { known individual life- } \\
\text { histories }\end{array}$ & 14 & $\begin{array}{l}\text { - Countries: Australia, } \\
\text { China, Denmark, } \\
\text { Germany, Malaysia, } \\
\text { Singapore, South } \\
\text { Korea, Thailand } \\
\text { - Serially sampled } \\
\text { species: Eonycteris } \\
\text { spelaea, Hipposideros } \\
\text { cervinus, Myotis } \\
\text { daubentonii, Myotis } \\
\text { macropus, Myotis } \\
\text { myotis, Pteropus lylei, }\end{array}$ & $\begin{array}{l}\text { - Some spatial and } \\
\text { temporal dynamics of } \\
\text { pathogens in } \\
\text { populations, and } \\
\text { maybe in individuals } \\
\text { - Spatiotemporal } \\
\text { patterns of infection } \\
\text { (e.g., travelling } \\
\text { waves) } \\
\text { - Transmission rates } \\
\text { and dynamics, using } \\
\text { carefully collected }\end{array}$ & $\begin{array}{l}\text { - Ability to identify and } \\
\text { isolate novel } \\
\text { pathogens } \\
\text { - May have ability to } \\
\text { repeatedly collect } \\
\text { covariate data or } \\
\text { track life-histories of } \\
\text { individuals } \\
\text { - More power to } \\
\text { exclude time- } \\
\text { invariant differences } \\
\text { between individuals, }\end{array}$ & $\begin{array}{l}\text { - May not be truly } \\
\text { longitudinal: without } \\
\text { known recapture of } \\
\text { individuals, repeated } \\
\text { longitudinal } \\
\text { monitoring at a } \\
\text { geographic location } \\
\text { may instead } \\
\text { represent multiple } \\
\text { cross-sectional } \\
\text { surveys of the } \\
\text { population }\end{array}$ \\
\hline
\end{tabular}




\begin{tabular}{|c|c|c|c|c|c|}
\hline Study type and & Number of studies & Overview & What we can learn & Advantages & Caveats \\
\hline & & $\begin{array}{l}\text { Rhinolophus sinicus, } \\
\text { Rousettus } \\
\text { leschenaultii }\end{array}$ & $\begin{array}{l}\text { age-prevalence and } \\
\text { age-seroprevalence } \\
\text { data } \\
\text { - Variation in } \\
\text { prevalence/seropreva } \\
\text { lence with host traits } \\
\text { or environmental } \\
\text { covariates } \\
\text { - Parameters of the } \\
\text { disease process in } \\
\text { individuals and } \\
\text { populations required } \\
\text { for dynamic modeling } \\
\text { (e.g., seasonality, } \\
\text { maybe transmission } \\
\text { rates, life-history } \\
\text { traits) } \\
\text { - Some dynamics of co- } \\
\text { circulating viruses } \\
\text { - Interventions that } \\
\text { might reduce } \\
\text { prevalence or } \\
\text { magnitude of an } \\
\text { epizootic or enzootic }\end{array}$ & $\begin{array}{l}\text { populations, or } \\
\text { environments } \\
\text { - Identification of } \\
\text { temporal trends (e.g., } \\
\text { seasonality) } \\
\text { - Potential for } \\
\text { forecasting and } \\
\text { prediction } \\
\text { - Intervention analysis } \\
\text { - Relationship between } \\
\text { time-series variables }\end{array}$ & $\begin{array}{l}\text { - Expensive, time- } \\
\text { consuming, and } \\
\text { logistically } \\
\text { challenging; slow } \\
\text { data acquisition } \\
\text { - Effective } \\
\text { implementation } \\
\text { requires a strong } \\
\text { ecological } \\
\text { understanding of the } \\
\text { study system and } \\
\text { collection of data to } \\
\text { determine sampling } \\
\text { frequency and } \\
\text { duration } \\
\text { - May be temporally } \\
\text { biased; sampling at } \\
\text { regular intervals may } \\
\text { consistently detect or } \\
\text { consistently miss vira } \\
\text { shedding } \\
\text { - May be spatially } \\
\text { biased; difficult to } \\
\text { sample spatially } \\
\text { replicated } \\
\text { populations } \\
\text { - Determining disease } \\
\text { dynamics is difficult: } \\
\text { requires consistent } \\
\text { recapture of } \\
\text { individuals, } \\
\text { longitudinal sampling } \\
\text { that exceeds } \\
\text { pathogen infectious } \\
\text { period, nonlethal }\end{array}$ \\
\hline
\end{tabular}




\begin{tabular}{|c|c|c|c|c|c|}
\hline Study type and & Number of studies & Overview & What we can learn & Advantages & Caveats \\
\hline & & & & & $\begin{array}{l}\text { pathogen detection, } \\
\text { and moderate } \\
\text { prevalence } \\
\text { - Large sample sizes, } \\
\text { spatially replicated } \\
\text { populations, and } \\
\text { short sampling } \\
\text { intervals are needed } \\
\text { to understand } \\
\text { environmental } \\
\text { drivers, and individual } \\
\text { and population-level } \\
\text { variation in viral } \\
\text { shedding } \\
\text { - Relationships that } \\
\text { exist for groups may } \\
\text { not apply to } \\
\text { individuals (ecological } \\
\text { fallacy, e.g., virus x } \\
\text { detected in all } \\
\text { population subgroups } \\
\text { sampled in Habitat A; } \\
\text { therefore, all } \\
\text { individuals or other } \\
\text { population subgroups } \\
\text { in Habitat A must also } \\
\text { carry virus x. }\end{array}$ \\
\hline $\begin{array}{l}\text { Cross-sectional } \\
\text { (intra-species) } \\
\text { Sampling of a bat } \\
\text { population or } \\
\text { population subgroup(s) } \\
\text { at a specific timepoint }\end{array}$ & 14 & & $\begin{array}{l}\text { - Genetic variation of } \\
\text { strains within host } \\
\text { population(s) } \\
\text { - Spatial distribution of } \\
\text { strains within host } \\
\text { population(s) } \\
\text { - Some differences } \\
\text { between }\end{array}$ & $\begin{array}{l}\text { - Relatively fast and } \\
\text { inexpensive } \\
\text { - Sampling of isolated } \\
\text { populations can help } \\
\text { distinguish between } \\
\text { population-level } \\
\text { pathogen persistence } \\
\text { and spatiotemporally } \\
\text { irregular transmission }\end{array}$ & $\begin{array}{l}\text { - No ability to detect } \\
\text { seasonality or other } \\
\text { temporal trends } \\
\text { - No causal inference } \\
\text { - Large amounts of } \\
\text { data are required to } \\
\text { account for variation }\end{array}$ \\
\hline
\end{tabular}




\begin{tabular}{|c|c|c|c|c|c|}
\hline Study type and & Number of studies & Overview & What we can learn & Advantages & Caveats \\
\hline & & & $\begin{array}{l}\text { demographic stages } \\
\text { (dependent on } \\
\text { sampling time-point) } \\
\text { - Possible to integrate } \\
\text { with longitudinal } \\
\text { studies of same } \\
\text { species } \\
\text { - Natural routes of } \\
\text { excretion }\end{array}$ & $\begin{array}{l}\text { - Can sample } \\
\text { populations } \\
\text { adaptively in } \\
\text { response to spillover } \\
\text { - Ability to isolate } \\
\text { pathogens } \\
\text { - Some ability to detect } \\
\text { spatial variation or } \\
\text { statistically analyze } \\
\text { differences. }\end{array}$ & $\begin{array}{l}\text { among individuals or } \\
\text { populations } \\
\text { - Effective } \\
\text { implementation } \\
\text { requires a strong } \\
\text { ecological } \\
\text { understanding of the } \\
\text { study system } \\
\text { - May be temporally } \\
\text { biased: sampling } \\
\text { during peaks or } \\
\text { troughs in population } \\
\text { prevalence will over- } \\
\text { or underestimate } \\
\text { geographic variation } \\
\text { in prevalence or } \\
\text { genetic diversity } \\
\text { - May be spatially } \\
\text { biased: at one } \\
\text { timepoint, different } \\
\text { population subgroups } \\
\text { may have peaks or } \\
\text { troughs in prevalence } \\
\text { Ecological fallacy (as } \\
\text { in longitudinal } \\
\text { studies) }\end{array}$ \\
\hline $\begin{array}{l}\text { Cross-sectional } \\
\text { (inter-species) } \\
\text { Sampling of bat } \\
\text { assemblages or a } \\
\text { subset of a bat } \\
\text { assemblage ( }>1 \text { species) } \\
\text { at a specific timepoint }\end{array}$ & 123 & $\begin{array}{l}\text { - Sampled countries: } \\
69 \\
\text { - Sampled bat families: } \\
18 \\
\text { - Positive bat families: } \\
14 \\
\text { - Sampled bat species: } \\
543\end{array}$ & $\begin{array}{l}\text { - Identity of potential } \\
\text { reservoir hosts } \\
\text { - Potential exchange of } \\
\text { strains between hosts } \\
\text { - Host and geographic } \\
\text { factors that impact } \\
\text { viral diversity }\end{array}$ & $\begin{array}{l}\text { - Rapid detection of } \\
\text { viruses in multiple } \\
\text { species } \\
\text { - Ability to isolate } \\
\text { pathogens } \\
\text { - Some ability to detect } \\
\text { species-level } \\
\text { differences }\end{array}$ & $\begin{array}{l}\text { - Same caveats as } \\
\text { intra-species cross- } \\
\text { sectional studies } \\
\text { - Often low sample } \\
\text { sizes for } \\
\text { opportunistically } \\
\text { sampled species } \\
\text { - Species bias: research } \\
\text { effort may }\end{array}$ \\
\hline
\end{tabular}




\begin{tabular}{|c|c|c|c|c|c|}
\hline Study type and & Number of studies & Overview & What we can learn & Advantages & Caveats \\
\hline & & $\begin{array}{l}\text { - Positive bat species: } \\
238\end{array}$ & & $\begin{array}{l}\text { - Relatively fast and } \\
\text { inexpensive }\end{array}$ & \begin{tabular}{|l|} 
inadvertently skew \\
importance of a \\
particular species as a \\
reservoir or spillover \\
host \\
- Ecological fallacy (as \\
in longitudinal and \\
intra-species cross- \\
sectional studies) \\
\end{tabular} \\
\hline $\begin{array}{l}\text { Multi-pathogen } \\
\text { detection } \\
\text { Detection of multiple } \\
\text { pathogens (virus } \\
\text { families, strains, or } \\
\text { other parasite taxa) } \\
\text { using metagenomic } \\
\text { sequencing or other } \\
\text { targeted methods on } \\
\text { samples collected } \\
\text { during cross-sectional } \\
\text { or longitudinal sampling } \\
\text { at the individual- or } \\
\text { population-level }\end{array}$ & 36 & & $\begin{array}{l}\text { - Viral species diversity, } \\
\text { abundance, and } \\
\text { community dynamics } \\
\text { - Some information } \\
\text { about periods of } \\
\text { potential spillover risk } \\
\text { for newly detected } \\
\text { viruses not yet known } \\
\text { to be zoonotic } \\
\text { - Coinfection and some } \\
\text { insight into } \\
\text { interactive effects of } \\
\text { viruses on hosts }\end{array}$ & $\begin{array}{l}\text { - Can be combined } \\
\text { with next-generation } \\
\text { sequencing to } \\
\text { identify viral } \\
\text { communities } \\
\text { - May require little to } \\
\text { no fieldwork if } \\
\text { samples are already } \\
\text { available } \\
\text { - Can be relatively } \\
\text { inexpensive with } \\
\text { rapid data acquisition } \\
\text { (design dependent) }\end{array}$ & $\begin{array}{l}\text { - Same caveats as } \\
\text { longitudinal or cross- } \\
\text { sectional studies, } \\
\text { depending on design } \\
\text { - May be difficult to } \\
\text { distinguish between } \\
\text { facilitative or } \\
\text { antagonistic } \\
\text { interactions between } \\
\text { coinfecting viruses or } \\
\text { viruses synchronously } \\
\text { shed from a bat } \\
\text { population; requires } \\
\text { large sample sizes } \\
\text { combined with } \\
\text { simulation or } \\
\text { experimental studies } \\
\text { - Drivers of multi-viral } \\
\text { infection or shedding } \\
\text { may be difficult to } \\
\text { detect (e.g., may be } \\
\text { driven by facilitative } \\
\text { interaction between } \\
\text { known or undetected } \\
\text { coinfecting viruses, } \\
\text { interactions with host } \\
\text { physiology/immunity, }\end{array}$ \\
\hline
\end{tabular}




\begin{tabular}{|c|c|c|c|c|c|}
\hline Study type and & Number of studies & Overview & What we can learn & Advantages & Caveats \\
\hline & & & & & \begin{tabular}{|l} 
and/or a response to \\
optimal \\
environmental \\
conditions) \\
- Biased detection: \\
high titers of one \\
virus in a sample may \\
reduce assay \\
sensitivity to other \\
viruses \\
- No causal inference \\
- Co-detection of \\
pathogens in pooled \\
or population-level \\
samples may reflect \\
coinfection or \\
contribution of \\
multiple bats to the \\
collected sample \\
\end{tabular} \\
\hline $\begin{array}{l}\text { Sequencing only } \\
\text { Viral sequencing on } \\
\text { samples collected } \\
\text { during longitudinal or } \\
\text { cross-sectional } \\
\text { sampling; little } \\
\text { collection of data on } \\
\text { other covariates }\end{array}$ & 29 & & $\begin{array}{l}\text { - Comparative } \\
\text { genomics } \\
\text { - Mutation and } \\
\text { evolutionary rates } \\
\text { - Virus discovery } \\
\text { - Effective population } \\
\text { size and genetic } \\
\text { diversity of virus } \\
\text { within or across } \\
\text { subpopulations } \\
\text { - Some information on } \\
\text { viral dynamics may be } \\
\text { possible (e.g., } \\
\text { through } \\
\text { phylodynamics) }\end{array}$ & $\begin{array}{l}\text { - Requires little } \\
\text { background } \\
\text { knowledge of study } \\
\text { system } \\
\text { - Relatively } \\
\text { inexpensive; rapid } \\
\text { data acquisition } \\
\text { - May require little to } \\
\text { no fieldwork if } \\
\text { samples are already } \\
\text { available }\end{array}$ & $\begin{array}{l}\text { - No ecological or } \\
\text { physiological context } \\
\text { - No causal inference }\end{array}$ \\
\hline
\end{tabular}


